\title{
Towards the development of new subtype-specific muscarinic receptor radiopharmaceuticals - Radiosynthesis and ex vivo biodistribution of [ ${ }^{18}$ F]3-(4-(2-(2-(2-fluoroethoxy)ethoxy)ethylthio)- 1,2,5-thiadiazol-3-yl)-1-methyl-1,2,5,6- tetrahydropyridine
}

\author{
Erik M. van Oosten, Alan A. Wilson, David C. Mamo, Bruce G. Pollock, \\ Benoit H. Mulsant, Sylvain Houle, and Neil Vasdev
}

\begin{abstract}
Muscarinic receptors have been implicated in neurological disorders including Alzheimer's disease, Parkinson's disease, and schizophrenia. Nineteen derivatives of thiadiazolyltetrahydropyridine (TZTP), a core that has previously shown high affinities towards muscarinic receptor subtypes, were synthesized and evaluated via in vitro binding assays. The title compound, a fluoro-polyethyleneglycol analog of TZTP (4c), was subsequently labelled with fluorine-18. Fluorine-18-labelled $\mathbf{4 c}$ was produced, via an automated synthesis, in an average radiochemical yield of $36 \%$ (uncorrected for decay), with high radiochemical purity (>99\%) and high specific activity (326 GBq/ $\mu \mathrm{mol}$; end-of-bombardment), within $40 \mathrm{~min}(n=3)$. Ex vivo biodistribution studies following tail-vein injection of $\left[{ }^{18} \mathrm{~F}\right] \mathbf{4 c}$ in conscious rats displayed sufficient brain uptake (0.4\%-0.7\% injected dose / gram of wet tissue in all brain regions at 5 min post injection); however, there were substantial polar metabolites present in the brain, thereby precluding future use of $\left[{ }^{18} \mathrm{~F}\right] \mathbf{4 c}$ for imaging in the central nervous system.
\end{abstract}

Key words: fluorine-18, muscarinic receptor, thiadiazolyltetrahydropyridine (TZTP), positron emission tomography (PET).

Résumé : Les récepteurs muscariniques ont été impliqués dans des désordres neurologiques, dont la maladie d'Alzheimer, la maladie de Parkinson et la schizophrénie. On a réalisé la synthèse de dix-neuf dérivés de la thiadiazolyltétrahydropyridine (TZTP), un produit fondamental pour lequel des études antérieures ont permis de montrer de grandes affinités vis-àvis des sous-types de récepteurs muscarinique, et on a évalué leurs propriétés par des essais de fixation in vitro. On a subséquemment marqué au fluor-18 le composé mentionné dans le titre (4c), un analogue fluoropolyéthylèneglycol de la TZTP. Le composé $\mathbf{4 c}$ marqué au fluor-18 a été obtenu, par le biais d'une synthèse automatisée, avec un rendement radiochimique de $36 \%$ (non corrigé pour la décroissance), avec une pureté radiochimique élevée (>99\%) et une activité spécifique élevée (326 GBq/ $\mu \mathrm{mol}$; fin du bombardement), en moins de 40 minutes $(n=3)$. Des études de biodistribution ex vivo à la suite d'injectons dans la veine de la queue du $\left[{ }^{18} \mathrm{~F}\right] \mathbf{4 c}$ dans des rats conscients ont démontré qu'il y se produit une absorption suffisante par le cerveau ( 0,4 à $0,7 \%$ de la dose injectée / gramme de tissu mouillé dans toutes les régions du cerveau cinq minutes après l'injection); toutefois, plusieurs métabolites polaires sont présents dans le cerveau et cette situation élimine l'usage dans le futur du $\left[{ }^{18} \mathrm{~F}\right] \mathbf{4 c}$ pour faire de l'imagerie du système nerveux central.

Mots-clés : fluor-18, récepteur muscarinique, thiadiazolyltétrahydropyridine (TZTP), tomographie à émission de positon (TEP).

[Traduit par la Rédaction]

Received 12 August 2010. Accepted 6 October 2010. Published on the NRC Research Press Web site at canjchem.nrc.ca on 24 November 2010.

E.M. van Oosten. PET Centre, Centre for Addiction and Mental Health, Toronto, ON M5T 1R8, Canada; Department of Chemistry, University of Toronto, Toronto, ON M5S 3H6, Canada.

A.A. Wilson, S. Houle, and N. Vasdev. ${ }^{1}$ PET Centre, Centre for Addiction and Mental Health, Toronto, ON M5T 1R8, Canada; Department of Psychiatry, University of Toronto, Toronto, ON M5T 1R8, Canada.

D.C. Mamo. PET Centre, Centre for Addiction and Mental Health, Toronto, ON M5T 1R8, Canada; Department of Psychiatry, University of Toronto, Toronto, ON M5T 1R8, Canada; Geriatric Mental Health Program, Centre for Addiction and Mental Health, Toronto, ON M6J 1H4, Canada.

B.G. Pollock and B.H. Mulsant. Department of Psychiatry, University of Toronto, Toronto, ON M5T 1R8, Canada; Geriatric Mental Health Program, Centre for Addiction and Mental Health, Toronto, ON M6J 1H4, Canada.

${ }^{1}$ Corresponding author (e-mail: neil.vasdev@camhpet.ca). 


\section{Introduction}

Muscarinic acetylcholine receptors (mAChRs) are present in both the peripheral and central nervous system (CNS) and are responsible for mediating the metabotropic effects of acetylcholine. ${ }^{1}$ There are 5 distinct subtypes of the muscarinic acetylcholine receptor, $\mathrm{M}_{1}, \mathrm{M}_{2}, \mathrm{M}_{3}, \mathrm{M}_{4}$, and $\mathrm{M}_{5}$, each having distinct functions and unique distributions in the CNS. ${ }^{2}$ The $\mathrm{M}_{1}$ and $\mathrm{M}_{2}$ receptors are abundant in the CNS and have postulated roles in Alzheimer's disease and schizophrenia, as well as a range of cognitive disorders. ${ }^{3,4}$ The $\mathrm{M}_{3}$ and $\mathrm{M}_{5}$ receptors are present in relatively lower concentrations in the CNS. ${ }^{3} \mathrm{M}_{3}$ receptors have no known correlations with neuropsychiatric disorders, whereas $\mathrm{M}_{5}$ receptors have been linked to schizophrenia and addictions. ${ }^{3,4}$ The $M_{4}$ receptor is present in the CNS, particularly in the cortex, striatum, and hippocampus, ${ }^{2,3}$ and is associated with Parkinson's disease and schizophrenia. ${ }^{1,4}$ The synthesis of subtype-selective drugs that target mAChRs is an ongoing goal in drug development. To date, the only clinically approved drugs that target mAChRs are nonselective antagonists that are used for treating patients suffering from Parkinson's disease.

Applying imaging modalities such as single photon emission computed tomography (SPECT) and positron emission tomography $(\mathrm{PET})^{5,6}$ to elucidate the mechanism of action of new pharmaceuticals targeting muscarinic receptors in vivo has been of long-standing interest. ${ }^{7}$ Derivatization of the thiadiazolyltetrahydropyridine (TZTP) core $^{8}$ has led to the development of muscarinic subtype-selective PET radiotracers. ${ }^{9-12}$ The $\mathrm{M}_{2}$-specific agonist radiotracer, fluorine-18 $\left({ }^{18} \mathrm{~F} ; t_{1 / 2}=109.7 \mathrm{~min}\right)$ labelled fluoropropylthio-TZTP ([18F]FP-TZTP), ${ }^{11,13,14}$ was proven to be selective through knockout mice studies ${ }^{15,16}$ and is currently the only $\mathbf{M}_{2^{-}}$ specific radiotracer established for human PET imaging. ${ }^{17,18}$ Fluorine-18-labelled FP-TZTP has been used to study risk factors of ageing ${ }^{19-21}$ and mood disorders. ${ }^{22,23}$

Driven largely by the theory that $\mathrm{M}_{1}$ receptor density is altered in the brain of patients with Alzheimer's disease in response to the degeneration of the cholinergic pathway, another TZTP derivative, 3-(4-(hexyloxy)-1,2,5-thiadiazol-3yl)-1-methyl-1,2,5,6-tetrahydropyridine (xanomeline), was found to exhibit $\mathrm{M}_{1} / \mathrm{M}_{4}$ selectivity. ${ }^{24}$ While it was found that xanomeline increased cognitive function of patients with Alzheimer's disease, several side effects precluded its therapeutic use. Carbon-11 $\left({ }^{11} \mathrm{C} ; t_{1 / 2}=20.4 \mathrm{~min}\right)$ labelled xanomeline was evaluated in human subjects ${ }^{9,25}$ and a ${ }^{18} \mathrm{~F}$ labelled xanomeline derivative was evaluated in rodents ${ }^{25}$ but neither radiopharmaceutical was further pursued because of inadequate receptor selectivity.

The present study sought to systematically prepare new muscarinic receptor subtype-specific TZTP analogs for development as PET radiopharmaceuticals. We report the synthesis of hydroxy- and fluoro-alkyl as well as hydroxy- and fluoro-polyethyleneglycol (PEG) ether and thioether analogs of TZTP, and the determination of their in vitro binding affinities $\left(K_{\mathrm{i}}\right)$ towards the five muscarinic subtypes, as well as $\sigma_{1}$ and $\sigma_{2}$ receptors. All analogs synthesized in this work are amenable to labelling with either ${ }^{18} \mathrm{~F}$ or ${ }^{11} \mathrm{C}$. A promising fluoro-PEG derivative of TZTP (4c), identified from initial in vitro screening, was radiolabelled with ${ }^{18} \mathrm{~F}$ and evaluated for its potential to image muscarinic receptors in the rodent brain.

\section{Results and discussion}

\section{Chemistry}

The syntheses of 19 derivatives of TZTP (Table 1) are reported, including previously known compounds (2a, ${ }^{13}$ $\mathbf{4 a},{ }^{11,12} \mathbf{8 a},{ }^{26} \mathbf{8 b},{ }^{26} \mathbf{9 c},{ }^{25}$ and $\left.\mathbf{1 0}^{8}\right)$. Syntheses of the TZTP analogs were carried out by literature procedures with modifications. Thioether-PEG analogs of TZTP, with both fluoro (4) and hydroxyl (2) groups at the terminal position, were synthesized as shown in Scheme 1. To conserve the TZTP core (3-(4-chloro-1,2,5-thiadiazol-3-yl)-1-methyl-1,2,5,6tetrahydropyridine; 1), ${ }^{8}$ fluoroalkyl and fluoro-PEG chains were synthesized from the respective diols (5, Scheme 2) for subsequent reactions with $\mathbf{1}$. The diols were disubstituted with benzyl-protecting and tosyloxy-leaving groups (6). $\mathrm{Nu}$ cleophilic displacement of the tosyloxy group of $\mathbf{6}$ with fluoride resulted in $O$-benzyl protected fluoroalkyl and fluoro-PEG chains (7). The hydroxyl analogs (8) were synthesized by reaction of the appropriate diol (5) with 1 (Scheme 3). Scheme 3 shows the synthesis of the desired fluoro-alkyl and fluoro-PEG ether-TZTP analogs (9), prepared by catalytic hydrogenation of 7 and in situ reaction with 1 in the presence of sodium hydride $(\mathrm{NaH})$. Several TZTP derivatives with incorporated PEG groups have been synthesized in attempts to achieve subtype selectivity and improve water solubility, binding affinity, and agonist potency toward mAChRs. ${ }^{27,28}$ The present work further explores the use of PEG groups as a means of expanding the series of TZTP derivatives, by replacing alkyl groups with PEG chains; [ ${ }^{18}$ F]fluoro-PEG groups have demonstrated similar pharmacological advantages when incorporated into PET radiopharmaceuticals. ${ }^{29}$ In preparation for in vitro binding assay studies, all 19 TZTP analogs synthesized in the present work (Table 1) were characterized by ${ }^{1} \mathrm{H}$ and ${ }^{19} \mathrm{~F}$ (when applicable) NMR spectroscopy, high resolution mass spectrometry, and elemental analysis (all compounds were $>97 \%$ pure by elemental analysis).

\section{In vitro binding assays}

The thioether-TZTP derivatives (compounds 2 and 4) as well as the ether derivatives (compounds 8-10) were evaluated by the National Institute of Mental Health's Psychoactive Drug Screening Program to determine their binding affinities towards each of the five muscarinic subtypes, as well as towards $\sigma_{1}$ and $\sigma_{2}$ receptors; the $\sigma$ receptors are known competition sites for ligands targeting mAChRs. ${ }^{30} \mathrm{In}$ the initial assay, all six thioether-TZTP derivatives (2a-2c and $\mathbf{4 a - 4 c}$ ) were measured for affinity towards the aforementioned receptors (Table S1 in the Supplementary data; values in parentheses), and a fluoro-PEG derivative of TZTP with moderate affinity towards the $\mathrm{M}_{4}$ receptor (4c; $K_{\mathrm{i}}=48 \mathrm{nM}$ ) was identified. Based on our initial binding assay, we advanced to radiolabelling this compound with fluorine-18, as it represents the first attempt to develop a PET radiotracer for imaging the $\mathrm{M}_{4}$ receptor and is a novel fluorinated-PEG derivative of TZTP. As such, our goal was 
Table 1. General structure and TZTP derivatives synthesized.

\begin{tabular}{|c|c|c|c|}
\hline \multirow[b]{2}{*}{ Structure } & \multicolumn{3}{|c|}{ TZTP derivatives } \\
\hline & $\mathbf{X}$ & $\mathbf{Y}$ & $\mathbf{Z}$ \\
\hline $2 \mathbf{a}$ & $\mathrm{S}$ & $\mathrm{CH}_{2} \mathrm{CH}_{2} \mathrm{CH}_{2}$ & $\mathrm{OH}$ \\
\hline $2 \mathbf{b}$ & $\mathrm{S}$ & $\mathrm{CH}_{2} \mathrm{CH}_{2} \mathrm{OCH}_{2} \mathrm{CH}_{2}$ & $\mathrm{OH}$ \\
\hline $2 c$ & $\mathrm{~S}$ & $\mathrm{CH}_{2} \mathrm{CH}_{2} \mathrm{OCH}_{2} \mathrm{CH}_{2} \mathrm{OCH}_{2} \mathrm{CH}_{2}$ & $\mathrm{OH}$ \\
\hline $4 \mathbf{a}$ & $\mathrm{S}$ & $\mathrm{CH}_{2} \mathrm{CH}_{2} \mathrm{CH}_{2}$ & $\mathrm{~F}$ \\
\hline $4 \mathbf{b}$ & $\mathrm{S}$ & $\mathrm{CH}_{2} \mathrm{CH}_{2} \mathrm{OCH}_{2} \mathrm{CH}_{2}$ & $\mathrm{~F}$ \\
\hline $4 c$ & $\mathrm{~S}$ & $\mathrm{CH}_{2} \mathrm{CH}_{2} \mathrm{OCH}_{2} \mathrm{CH}_{2} \mathrm{OCH}_{2} \mathrm{CH}_{2}$ & $\mathrm{~F}$ \\
\hline 8a & $\mathrm{O}$ & $\mathrm{CH}_{2} \mathrm{CH}_{2} \mathrm{CH}_{2}$ & $\mathrm{OH}$ \\
\hline $8 \mathbf{b}$ & $\mathrm{O}$ & $\mathrm{CH}_{2} \mathrm{CH}_{2} \mathrm{CH}_{2} \mathrm{CH}_{2}$ & $\mathrm{OH}$ \\
\hline $8 c$ & $\mathrm{O}$ & $\mathrm{CH}_{2} \mathrm{CH}_{2} \mathrm{CH}_{2} \mathrm{CH}_{2} \mathrm{CH}_{2}$ & $\mathrm{OH}$ \\
\hline 8d & $\mathrm{O}$ & $\mathrm{CH}_{2} \mathrm{CH}_{2} \mathrm{CH}_{2} \mathrm{CH}_{2} \mathrm{CH}_{2} \mathrm{CH}_{2}$ & $\mathrm{OH}$ \\
\hline $8 \mathbf{e}$ & $\mathrm{O}$ & $\mathrm{CH}_{2} \mathrm{CH}_{2} \mathrm{OCH}_{2} \mathrm{CH}_{2}$ & $\mathrm{OH}$ \\
\hline $\mathbf{8 f}$ & $\mathrm{O}$ & $\mathrm{CH}_{2} \mathrm{CH}_{2} \mathrm{OCH}_{2} \mathrm{CH}_{2} \mathrm{OCH}_{2} \mathrm{CH}_{2}$ & $\mathrm{OH}$ \\
\hline $9 \mathbf{a}$ & $\mathrm{O}$ & $\mathrm{CH}_{2} \mathrm{CH}_{2} \mathrm{CH}_{2}$ & $\mathrm{~F}$ \\
\hline $9 b$ & $\mathrm{O}$ & $\mathrm{CH}_{2} \mathrm{CH}_{2} \mathrm{CH}_{2} \mathrm{CH}_{2} \mathrm{CH}_{2}$ & $\mathrm{~F}$ \\
\hline 9c & $\mathrm{O}$ & $\mathrm{CH}_{2} \mathrm{CH}_{2} \mathrm{CH}_{2} \mathrm{CH}_{2} \mathrm{CH}_{2} \mathrm{CH}_{2}$ & $\mathrm{~F}$ \\
\hline 9d & $\mathrm{O}$ & $\mathrm{CH}_{2} \mathrm{CH}_{2} \mathrm{CH}_{2} \mathrm{CH}_{2} \mathrm{CH}_{2} \mathrm{CH}_{2} \mathrm{CH}_{2}$ & $\mathrm{~F}$ \\
\hline $9 \mathrm{e}$ & $\mathrm{O}$ & $\mathrm{CH}_{2} \mathrm{CH}_{2} \mathrm{OCH}_{2} \mathrm{CH}_{2}$ & $\mathrm{~F}$ \\
\hline 9f & $\mathrm{O}$ & $\mathrm{CH}_{2} \mathrm{CH}_{2} \mathrm{OCH}_{2} \mathrm{CH}_{2} \mathrm{OCH}_{2} \mathrm{CH}_{2}$ & $\mathrm{~F}$ \\
\hline 10 & $\mathrm{O}$ & $\mathrm{CH}_{2} \mathrm{CH}_{2} \mathrm{CH}_{2} \mathrm{CH}_{2} \mathrm{CH}_{2} \mathrm{CH}_{2}$ & $\mathrm{H}$ \\
\hline
\end{tabular}

to radiolabel the title compound, $4 \mathbf{c}$, with ${ }^{18} \mathrm{~F}$ and evaluate its potential for imaging the CNS via a preliminary ex vivo biodistribution study.

\section{Radiochemistry}

The radiosynthetic approach for $\left[{ }^{18} \mathrm{~F}\right] \mathbf{4 c}$ was similar to our previously reported synthesis for $\left[{ }^{18} \mathrm{~F}\right] \mathrm{FP}-\mathrm{TZTP},{ }^{14}$ where the appropriate tosyloxy-containing radiolabelling precursor (3c) was subjected to reaction with fluorine-18-labelled potassium cryptand fluoride $\left(\mathrm{K}\left[{ }^{18} \mathrm{~F}\right] / \mathrm{K}_{222}\right)$ in $\mathrm{CH}_{3} \mathrm{CN}$ at $90{ }^{\circ} \mathrm{C}$ for 10 min (Scheme 4) followed by HPLC purification (Fig. 1). The formulated product was $>99 \%$ radiochemically pure (Fig. 2) and the $\log D$ was experimentally determined to be $1.73 \pm 0.01(\mathrm{pH}=7.4)$, using a previously reported method. ${ }^{31}$ The automated synthesis of $\left[{ }^{18} \mathrm{~F}\right] \mathbf{4 c}$ resulted in a radiochemical yield of $35.6 \% \pm 15.3 \%$ based on $\left[{ }^{18} \mathrm{~F}\right]$ fluoride and uncorrected for decay in a synthesis time of $37 \mathrm{~min}(n=$ $3)$. The specific activity of $\left[{ }^{18} \mathrm{~F}\right] 4 \mathrm{c}$ was $326 \pm 198 \mathrm{GBq} / \mu \mathrm{mol}$ (corrected to end-of-bombardment). Fluorine-18-labelled 4c is the first reported ${ }^{18} \mathrm{~F}$-labelled PEG derivative of TZTP. While the hydroxyl derivatives of TZTP (series $\mathbf{2}$ and $\mathbf{8}$ ) are not amenable to labelling with ${ }^{18} \mathrm{~F}$, similar compounds have been readily labelled by reaction of the respective desmethyl precursors with $\left[{ }^{11} \mathrm{C}\right] \mathrm{CH}_{3} \mathrm{I} \cdot{ }^{9,12}$
Ex vivo biodistribution in rodents

Preliminary ex vivo biodistribution studies using $\left[{ }^{18} \mathrm{~F}\right] \mathbf{4 c}$ were subsequently carried out in conscious male SpragueDawley rats. ${ }^{32,33}$ Fluorine-18-labelled $\mathbf{4 c}$ demonstrated fast and efficient uptake in the rodent brain $(0.4 \%-0.7 \%$ injected dose / gram of wet tissue in all brain regions at 5 min post injection) following tail-vein injection (Fig. S1 in the Supplementary data). This uptake was followed by a fast washout, with most of the radioactivity cleared from the brain by 15 min. Radio-HPLC analysis of plasma identified a rapid degradation of the parent compound to both hydrophilic and lipophilic metabolites. At $15 \mathrm{~min}$ after injection of $\left[{ }^{18} \mathrm{~F}\right] 4 \mathrm{c}$ only $4.5 \%$ of the parent compound was unmetabolized. Analysis of brain homogenates $60 \mathrm{~min}$ after injection (Fig. 3) found that while the parent compound was present in the brain, there was a significant accumulation of radioactive polar metabolites (24\%). Owing to the presence of radioactive metabolites in the brain, further studies were not justified because $\left[{ }^{18} \mathrm{~F}\right] \mathbf{4 c}$ does not present suitable properties for imaging the CNS.

\section{Conclusion}

We report the synthesis of 13 new TZTP derivatives that are amenable for radiolabelling with ${ }^{11} \mathrm{C}$ and (or) ${ }^{18} \mathrm{~F}$. Com- 
Scheme 1. General syntheses of thioether-TZTP derivatives and radiolabelling precursors. (i) 1, $\mathrm{Li}_{2} \mathrm{~S}$, DMF; 2, bromo- or chloro-alcohol, $\mathrm{K}_{2} \mathrm{CO}_{3}$, DMF. (ii) TsCl, Et 3 N, DMAP, $\mathrm{CH}_{2} \mathrm{Cl}_{2}$. (iii) TBAF, THF.<smiles>CN1CCC=C(c2nsnc2SCCCO)C1</smiles>

I $2 a$

ii<smiles>CN1CCC=C(c2nsnc2SCCC[SeH2])C1</smiles><smiles>[131In]</smiles><smiles>CN1CCC=C(c2nsnc2SCCCF)C1</smiles><smiles>CC(C)C</smiles>

1<smiles>CN1CCC=C(c2nsnc2SCCOCC(C)(O)C=[V])C1</smiles>

2b,c ii<smiles>CN1CCC=C(c2nsnc2SCCOCC(C)(O)O[Sb])C1</smiles><smiles>CN1CCC=C(c2nsnc2SCCOCCC(C)(F)F)C1</smiles>

$4 b, c$

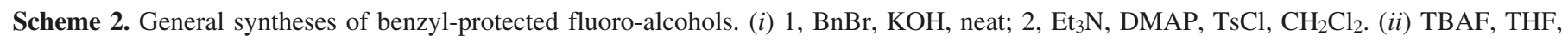
microwave heating.

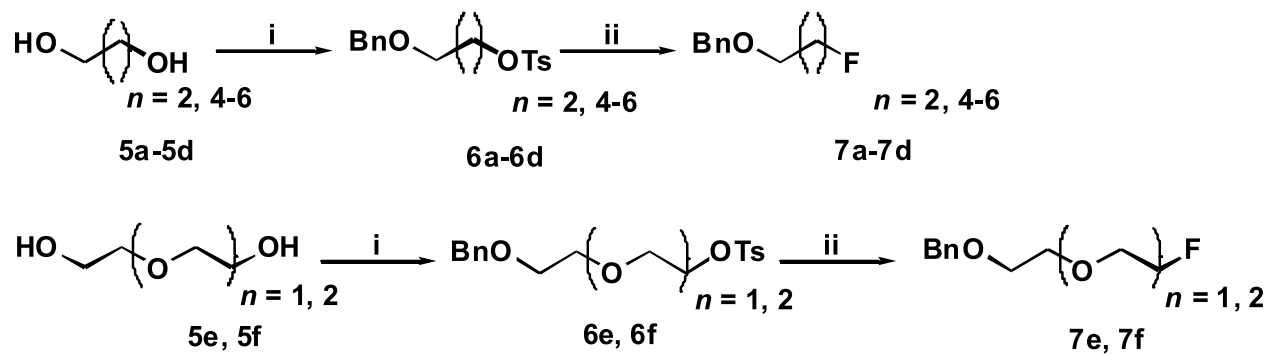

Scheme 3. General syntheses of ether-TZTP derivatives. (i) 5a-5f, NaH, THF. (ii) 1, Pd/C, Pd(OH) $)_{2} \mathrm{H}_{2}(\mathrm{~g}), \mathrm{THF} ; 2$, NaH, 1, THF.

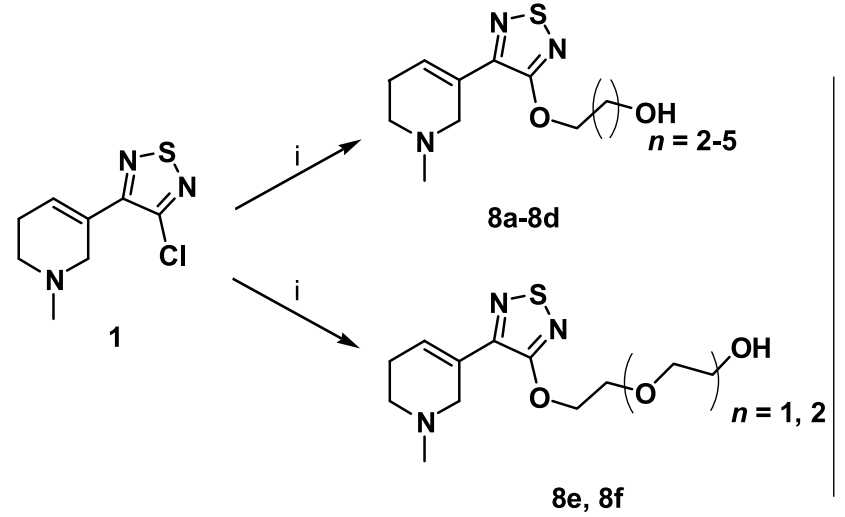

pound $\mathbf{4 c}$ was chosen as a lead compound for radiolabelling based on in vitro binding assays and represents the first fluoroPEG derivative of TZTP. Automated radiosynthesis of $\left[{ }^{18} \mathrm{~F}\right] 4 \mathrm{c}$ was achieved with good radiochemical yields, high specific activity, and excellent radiochemical purity within

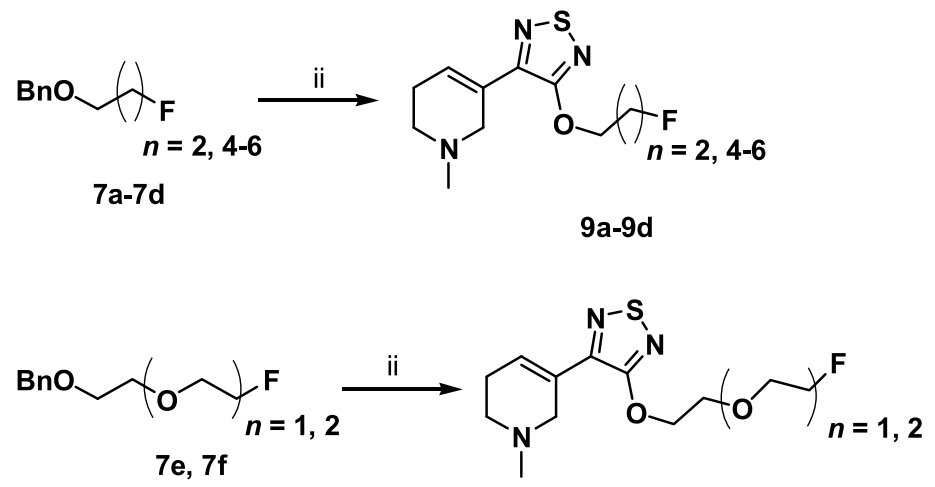

9e, $9 f$

40 min. Ex vivo biodistribution studies in rodent models showed appreciable amounts of polar radioactive metabolites in the brain, suggesting that $\left[{ }^{18} \mathrm{~F}\right] \mathbf{4 c}$ is not suitable for further development as a radiopharmaceutical for imaging the CNS. 
Scheme 4. Radiosynthesis of $\left[{ }^{18} \mathrm{~F}\right] \mathbf{4 c}$. RCY = radiochemical yield, not corrected for decay.

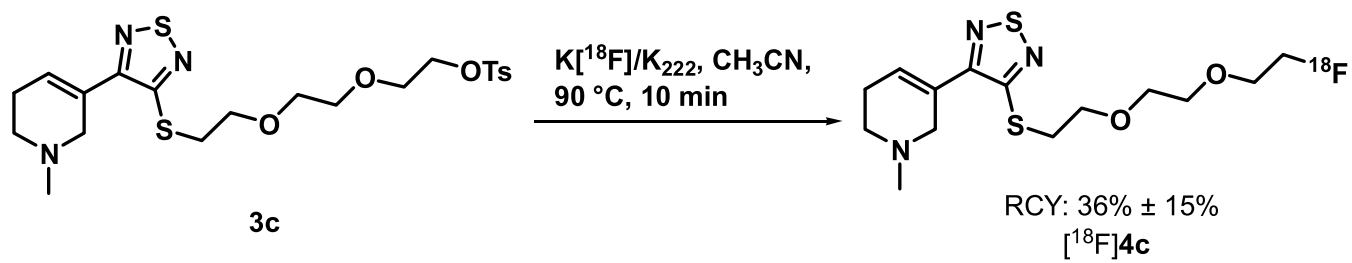

Fig. 1. Semipreparative HPLC purification $\left(20: 80 \mathrm{CH}_{3} \mathrm{CN}: \mathrm{H}_{2} \mathrm{O}+\right.$ $0.1 \mathrm{~N}$ ammonium formate $+1 \%$ formic acid $(\mathrm{pH} 4)$, Semi-Prep LUNA C18(2) $(250 \mathrm{~mm} \times 10 \mathrm{~mm}, 10 \mu \mathrm{m}, \lambda=254 \mathrm{~nm})$ at $6 \mathrm{~mL} /$ $\min )$ of $\left[{ }^{18} \mathrm{~F}\right] \mathbf{4 c}\left(t_{\mathrm{R}}=13 \mathrm{~min}\right)$.

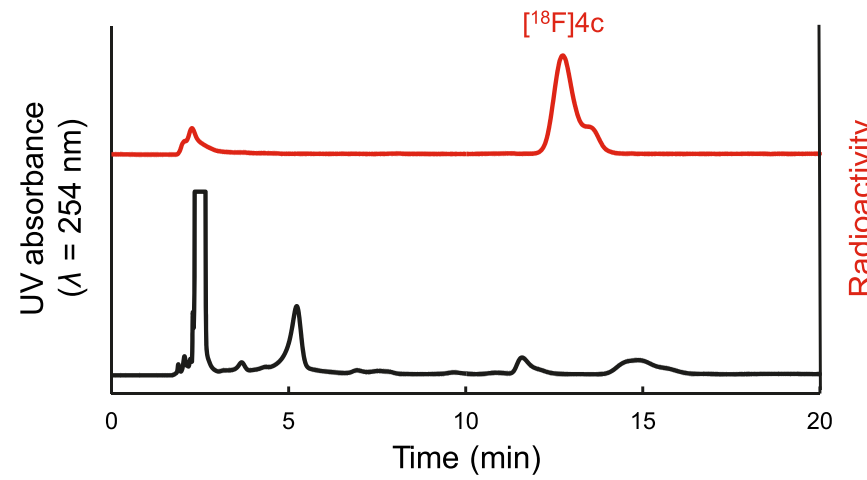

Fig. 2. Analytical HPLC (Phenomenex Prodigy C18 (ODS prep), 30:70 $\mathrm{CH}_{3} \mathrm{CN}: \mathrm{H}_{2} \mathrm{O}+0.1 \mathrm{~N}$ ammonium formate; $\lambda=254 \mathrm{~nm}$; $3.0 \mathrm{~mL} / \mathrm{min}$ ) of purified $\left[{ }^{18} \mathrm{~F}\right] \mathbf{4 c}$ (from top to bottom: gamma, $\mathrm{UV}$ $(254 \mathrm{~nm})$, and UV spiked with $\left.4 \mathrm{c}(254 \mathrm{~nm}) ; t_{\mathrm{R}}=3.2 \mathrm{~min}\right)$.

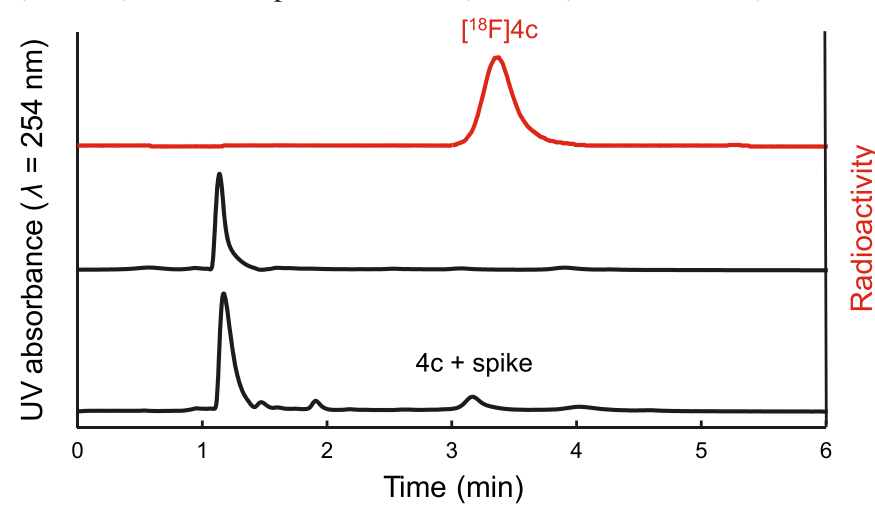

\section{Experimental section}

\section{General methods}

3-Chloro-(pyridine-3-yl)-1,2,5-thiadiazole was purchased from commercial suppliers and was used as received without further purification unless otherwise specified. Compound $\mathbf{1}$, 3-(3-chloro-1,2,5-thiadiazol-4-yl)-1,2,5,6-tetrahydro-1-methylpyridine, ${ }^{8}$ and compound 3a, 3-(4-(1-methyl-1,2,5,6-tetrahydropyridin-3-yl)-1,2,5-thiadiazol-3-ylthio)propyl-4-methylbenzenesulfonate, ${ }^{14}$ were prepared by literature procedures. All water used was distilled and deionized and all mobile phases were made with HPLC-grade solvents. Flash column
Fig. 3. HPLC analysis (see the Metabolism studies section for HPLC conditions) of rat brain homogenates at $60 \mathrm{~min}$ post injection of $\left[{ }^{18} \mathrm{~F}\right] \mathbf{4 c}$.

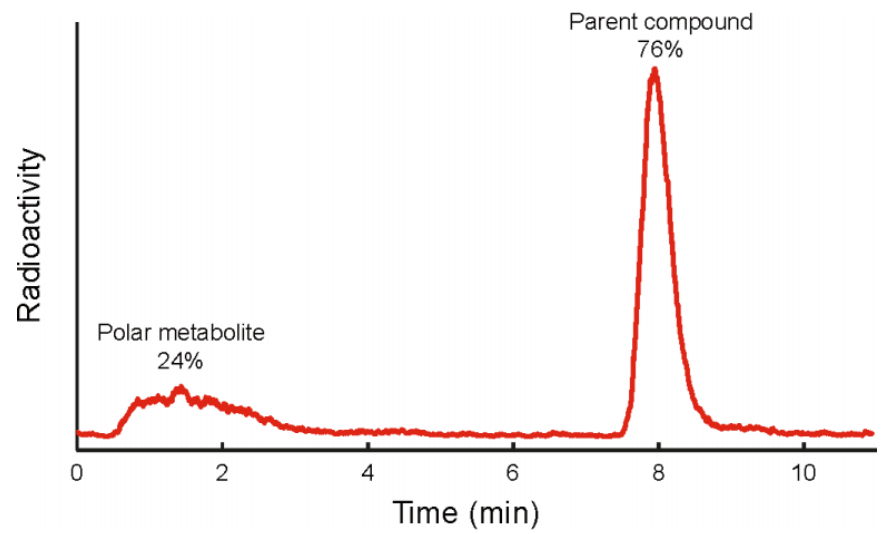

chromatography purification was accomplished using silica gel 60 (63-200 $\mu \mathrm{m}$, Caledon). Preparative thin-layer chromatography (PTLC) was accomplished using silica gel GF plates $(20 \mathrm{~cm} \times 20 \mathrm{~cm}, 2000 \mu \mathrm{m})$ from Analtech. All new compounds were obtained as oils following purification.

High resolution mass spectrometry (HR-MS) was conducted by the Advanced Instrumentation for Molecular Structure Laboratory or by the Centre for Biological Timing and Cognition at the University of Toronto. Elemental analysis (EA) was performed by the Analytical Laboratory for Environmental Science Research and Training, University of Toronto. Proton and carbon-13 NMR spectra were recorded at $25{ }^{\circ} \mathrm{C}$ in $\mathrm{CDCl}_{3}$ on a Varian Mercury $300 \mathrm{MHz}$ or $400 \mathrm{MHz}$ spectrometer with an autoswitchable $\mathrm{H} / \mathrm{F} / \mathrm{C} / \mathrm{P}$ $5 \mathrm{~mm}$ probe with gradients. Proton NMR chemical shifts were reported using either tetramethylsilane (TMS, $0.00 \mathrm{ppm}$ ) as an internal standard or referencing to the residual proton in $\mathrm{CDCl}_{3}$ (7.26 ppm). The proton resonances of primary alcohols were often not observed owing to exchange. For ${ }^{13} \mathrm{C} \mathrm{NMR}$, shifts were referenced to $\mathrm{CDCl}_{3}$ (77.0 ppm). Fluorine-19 NMR shifts were referenced to external $\mathrm{CFCl}_{3}(0.00 \mathrm{ppm})$. Tetrabutylammonium fluoride (TBAF) was prepared by evaporation of tetrahydrofuran (THF) from a $1.0 \mathrm{M}$ solution under reduced pressure, and then drying under reduced pressure overnight, as modified from a previously reported literature procedure. ${ }^{34}$ THF was freshly distilled over lithium aluminum hydride $\left(\mathrm{LiAlH}_{4}\right)$.

All animal experiments were carried out under humane conditions, with approval from the Animal Care Committee at the Centre for Addiction and Mental Health and in accordance with the guidelines set forth by the Canadian Council on Animal Care. 


\section{Chemical synthesis}

3-(4-(1-Methyl-1,2,5,6-tetrahydropyridin-3-yl)-1,2,5thiadiazol-3-ylthio)propan-1-ol (2a)

Compound 2a was prepared by minor modifications to a literature procedure. ${ }^{13}$ Briefly, $250 \mathrm{mg}$ of 1 (1.16 mmol) was dissolved in $3 \mathrm{~mL}$ of anhydrous DMF in an oven-dried round-bottomed flask under nitrogen. $\mathrm{Li}_{2} \mathrm{~S}(2.9 \mathrm{mmol})$ was added to the mixture with stirring at $60{ }^{\circ} \mathrm{C}$ in an oil bath for $5 \mathrm{~h}$. Upon consumption of the starting material, the reaction was cooled to room temperature (RT) and 3-bromopropanol $(2.9 \mathrm{mmol})$ was added, followed by addition of $\mathrm{K}_{2} \mathrm{CO}_{3}(2.9 \mathrm{mmol})$. The reaction mixture was stirred at RT for $35 \mathrm{~min}$. Upon completion, the reaction was diluted with ether $(50 \mathrm{~mL})$, washed with $\mathrm{H}_{2} \mathrm{O}(3 \times 50 \mathrm{~mL})$ and brine $(50 \mathrm{~mL})$, dried over $\mathrm{NaSO}_{4}$, and concentrated. PTLC purification was performed (20:80 EtOAc:Hex) to yield $217 \mathrm{mg}$ of $2 \mathbf{a}(69 \%) .{ }^{1} \mathrm{H}$ NMR $\left(\mathrm{CDCl}_{3}, 300 \mathrm{MHz}\right) \delta$ : 6.77-6.71 (m, $1 \mathrm{H}), 3.71\left(\mathrm{t},{ }^{3} J_{\mathrm{HH}}=5.9 \mathrm{~Hz}, 2 \mathrm{H}\right), 3.45-3.42(\mathrm{~m}, 2 \mathrm{H}), 3.37(\mathrm{t}$, $\left.{ }^{3} J_{\mathrm{HH}}=6.9 \mathrm{~Hz}, 2 \mathrm{H}\right), 3.22(\mathrm{br}, 1 \mathrm{H}), 2.63-2.57(\mathrm{~m}, 2 \mathrm{H}), 2.51-$ $2.43(\mathrm{~m}, 2 \mathrm{H}), 2.47(\mathrm{~s}, 3 \mathrm{H}), 2.04-1.91$ (m, 2H). HR-MS calcd. for $\mathrm{C}_{11} \mathrm{H}_{18} \mathrm{~N}_{3} \mathrm{OS}_{2}[\mathrm{M}+1]$ : 272.0897; found: 272.0885. EA calcd.: C 48.68, H 6.33, N 15.49; found: C 48.39, H 6.46, N 14.90.

\section{2-(2-(4-(1-Methyl-1,2,5,6-tetrahydropyridin-3-yl)-1,2,5- thiadiazol-3-ylthio)ethoxy)ethanol (2b)}

The general procedure for the synthesis of $\mathbf{2 a}$ was followed using 1 (1.16 mmol) in DMF with 2.5 equiv. of $\mathrm{Li}_{2} \mathrm{~S}$, 2.5 equiv. of 2-(2-chloroethoxy)ethanol, and 2.5 equiv. of $\mathrm{K}_{2} \mathrm{CO}_{3}$ to give $304 \mathrm{mg}$ of $\mathbf{2 b}(87 \%)$ after PTLC purification. ${ }^{1} \mathrm{H}$ NMR $\left(\mathrm{CDCl}_{3}, 300 \mathrm{MHz}\right) \delta: 6.77-6.72(\mathrm{~m}, 1 \mathrm{H}), 3.84(\mathrm{t}$, $\left.{ }^{3} J_{\mathrm{HH}}=6.3 \mathrm{~Hz}, 2 \mathrm{H}\right), 3.76-3.72(\mathrm{~m}, 2 \mathrm{H}), 3.64-3.59(\mathrm{~m}, 2 \mathrm{H})$, $3.51\left(\mathrm{t},{ }^{3} J_{\mathrm{HH}}=6.3 \mathrm{~Hz}, 2 \mathrm{H}\right), 3.45-3.42(\mathrm{~m}, 2 \mathrm{H}), 2.63-2.57$ (m, 2H), 2.52-2.44 (m, 2H), 2.46 (s, 3H). HR-MS calcd. for $\mathrm{C}_{12} \mathrm{H}_{20} \mathrm{~N}_{3} \mathrm{O}_{2} \mathrm{~S}_{2}[\mathrm{M}+1]$ : 302.0991; found: 302.0990. EA calcd.: C 47.81, H 6.37, N 13.94: found: C 47.92, H 6.32, $\mathrm{N} 13.60$.

\section{2-(2-(2-(4-(1-Methyl-1,2,5,6-tetrahydropyridin-3-yl)-1,2,5- thiadiazol-3-ylthio)ethoxy)ethoxy)ethanol (2c)}

The general procedure for the synthesis of $\mathbf{2 a}$ was followed using 1 (1.16 mmol) in DMF with 2.5 equiv. of $\mathrm{Li}_{2} \mathrm{~S}$, 2.5 equiv. of 2-(2-(2-chloroethoxy)ethoxy)ethanol, and 2.5 equiv. of $\mathrm{K}_{2} \mathrm{CO}_{3}$. After PTLC purification, 2c was obtained in a $95 \%$ yield $(542 \mathrm{mg}) .{ }^{1} \mathrm{H}$ NMR $\left(\mathrm{CDCl}_{3}\right.$, $300 \mathrm{MHz}) \delta: 6.77-6.71(\mathrm{~m}, 1 \mathrm{H}), 3.83(\mathrm{~m}, 2 \mathrm{H}), 3.75-3.71$ $(\mathrm{m}, 2 \mathrm{H}), 3.69-3.66(\mathrm{~m}, 4 \mathrm{H}), 3.63-3.59(\mathrm{~m}, 2 \mathrm{H}), 3.51(\mathrm{t}$, $\left.{ }^{3} J_{\mathrm{HH}}=6.5 \mathrm{~Hz}, 2 \mathrm{H}\right), 3.45-3.42(\mathrm{~m}, 2 \mathrm{H}), 2.63-2.59(\mathrm{~m}, 2 \mathrm{H})$, 2.52-2.45 (m, 2H), 2.46 (s, 3H). HR-MS calcd. for $\mathrm{C}_{14} \mathrm{H}_{24} \mathrm{~N}_{3} \mathrm{O}_{3} \mathrm{~S}_{2}[\mathrm{M}+1]$ : 346.1253; found: 346.1266. EA calcd.: C 48.67, H 6.72, N 12.17; found: C 47.64, H 6.88, N 11.83

\section{2-(2-(4-(1-Methyl-1,2,5,6-tetrahydropyridin-3-yl)-1,2,5- thiadiazol-3-ylthio)ethoxy)ethyl 4-methylbenzenesulfonate (3b)}

Compound $\mathbf{3 b}$ was made by an analogous procedure to that of compound 3a. ${ }^{14}$ Briefly, $267 \mathrm{mg}(0.89 \mathrm{mmol})$ of $\mathbf{2 b}$ was dissolved in $8 \mathrm{~mL}$ of $\mathrm{CH}_{2} \mathrm{Cl}_{2}$ followed by the addition of 1.5 equiv. of $p$-toluenesulfonyl chloride ( $\mathrm{TsCl}), 3$ equiv. of triethylamine (TEA), and a catalytic amount of dimethy- laminopyridine (DMAP; 1 mol\%). Compound 3b was obtained in an $86 \%$ yield (348 $\mathrm{mg}) .{ }^{1} \mathrm{H} \mathrm{NMR}\left(\mathrm{CDCl}_{3}\right.$, $300 \mathrm{MHz}) \delta$ : 7.82-7.76 (m, 2H), 7.35-7.29 (m, 2H), 6.75$6.70(\mathrm{~m}, 1 \mathrm{H}), 4.19-4.14(\mathrm{~m}, 2 \mathrm{H}), 3.74\left(\mathrm{t},{ }^{3} J_{\mathrm{HH}}=6.3 \mathrm{~Hz}\right.$, 2H), 3.71-3.66 (m, 2H), 3.44-3.36 (m, 4H), 2.62-2.56 (m, $2 \mathrm{H}), 2.51-2.42(\mathrm{~m}, 8 \mathrm{H})$.

\section{2-(2-(2-(4-(1-Methyl-1,2,5,6-tetrahydropyridin-3-yl)-1,2,5- thiadiazol-3-ylthio)ethoxy)ethoxy)ethyl 4- methylbenzenesulfonate $(3 c)$}

Compound $\mathbf{3 c}$ was made by an analogous procedure to that of compound 3a. ${ }^{14}$ Briefly, $350 \mathrm{mg}(1.01 \mathrm{mmol})$ of $\mathbf{2 c}$ was dissolved in $8 \mathrm{~mL}$ of $\mathrm{CH}_{2} \mathrm{Cl}_{2}$ followed by the addition of 1.5 equiv. of $\mathrm{TsCl}, 3$ equiv. of $\mathrm{TEA}$, and catalytic DMAP (1 mol\%). Compound 3c was obtained in a $72 \%$ yield $(352 \mathrm{mg}) .{ }^{1} \mathrm{H} \mathrm{NMR}\left(\mathrm{CDCl}_{3}, 400 \mathrm{MHz}\right) \delta: 7.82-7.78$ (m, 2H), 7.65-7.31 (m, 2H), 6.77-6.73 (m, 1H), 4.18-4.15 $(\mathrm{m}, 2 \mathrm{H}), 3.79\left(\mathrm{t},{ }^{2} J_{\mathrm{HF}}=6.4 \mathrm{~Hz}, 2 \mathrm{H}\right), 3.71-3.68(\mathrm{~m}, 2 \mathrm{H})$, $3.61-3.59(\mathrm{~m}, 4 \mathrm{H}), 3.48\left(\mathrm{t},{ }^{3} J_{\mathrm{HH}}=6.6 \mathrm{~Hz}, 2 \mathrm{H}\right), 3.44-3.42$ (m, 2H), 2.62-2.58 (m, 2H), 2.49-2.43 (m, 8H).

\section{3-(4-(3-Fluoropropylthio)-1,2,5-thiadiazol-3-yl)-1-methyl- 1,2,5,6-tetrahydropyridine (4a)}

Compound 4a was prepared by modifications to the literature procedures. ${ }^{11,13}$ To an oven-dried round-bottomed flask containing $4.9 \mathrm{mmol}$ TBAF (dried under reduced pressure overnight) was added $10 \mathrm{~mL}$ of freshly distilled THF, followed by $0.33 \mathrm{mmol}$ of $\mathbf{3 a}$. The reaction was refluxed for $3 \mathrm{~h}$ and then diluted with $50 \mathrm{~mL} \mathrm{H}_{2} \mathrm{O}$ and washed with $50 \mathrm{~mL}$ of EtOAc $(\times 2)$. The combined organic layer was washed with $50 \mathrm{~mL}$ of brine, dried over $\mathrm{Na}_{2} \mathrm{SO}_{4}$, and concentrated. The product was purified using PTLC (7:93 $\mathrm{MeOH}: \mathrm{CH}_{2} \mathrm{Cl}_{2}$ ) to yield $37 \mathrm{mg}$ of $4 \mathbf{a}(36 \%)$. ${ }^{1} \mathrm{H} \mathrm{NMR}$ $\left(\mathrm{CDCl}_{3}, 300 \mathrm{MHz}\right) \delta: 6.70-6.65(\mathrm{~m}, 1 \mathrm{H}), 4.52\left(\mathrm{dt},{ }^{2} J_{\mathrm{HF}}=\right.$ $\left.47.1 \mathrm{~Hz},{ }^{3} J_{\mathrm{HH}}=5.6 \mathrm{~Hz}, 2 \mathrm{H}\right), 3.39-3.35(\mathrm{~m}, 2 \mathrm{H}), 3.33(\mathrm{t}$, $\left.{ }^{3} J_{\mathrm{HH}}=7.22 \mathrm{~Hz}, 2 \mathrm{H}\right), 2.56-2.49(\mathrm{~m} .2 \mathrm{H}), 2.44-2.37(\mathrm{~m}$, $2 \mathrm{H}), 2.39(\mathrm{~s}, 3 \mathrm{H}), 2.12\left(\mathrm{dm},{ }^{3} J_{\mathrm{HF}}=26.5 \mathrm{~Hz}, 2 \mathrm{H}\right) .{ }^{19} \mathrm{~F} \mathrm{NMR}$ $\left(\mathrm{CDCl}_{3}, 282 \mathrm{MHz}\right) \delta:-221.51\left(\mathrm{tt},{ }^{2} J_{\mathrm{HF}}=47.2 \mathrm{~Hz},{ }^{3} J_{\mathrm{HF}}=\right.$ $26.5 \mathrm{~Hz}$ ). HR-MS calcd. for $\mathrm{C}_{11} \mathrm{H}_{16} \mathrm{FN}_{3} \mathrm{~S}_{2}$ [M]: 273.0770; found: 273.0772. EA calcd.: C 48.32, H 5.91, N 15.37; found: C 48.23, H 6.03, N 15.12.

\section{3-(2-(2-Fluoroethoxy)ethylthio)-4-(1-methyl-1,2,5,6- tetrahydropyridin-3-yl)-1,2,5-thiadiazole (4b)}

Compound $\mathbf{4 b}$ was prepared in an analogous manner to that of $\mathbf{4 a}$. Briefly, $0.3 \mathrm{mmol}$ of $\mathbf{3 b}$ in THF was reacted with 5 equiv. of TBAF. $\mathbf{4 b}$ was obtained in a $33 \%$ yield (36 mg). ${ }^{1} \mathrm{H} \mathrm{NMR}\left(\mathrm{CDCl}_{3}, 300 \mathrm{MHz}\right) \delta: 6.79-6.75(\mathrm{~m}, 1 \mathrm{H})$, $4.57\left(\mathrm{dm},{ }^{2} J_{\mathrm{HF}}=47.6 \mathrm{~Hz}, 2 \mathrm{H}\right), 3.86\left(\mathrm{t},{ }^{3} J_{\mathrm{HH}}=6.43 \mathrm{~Hz}, 2 \mathrm{H}\right)$, $3.76\left(\mathrm{dm},{ }^{3} J_{\mathrm{HF}}=29.5 \mathrm{~Hz}, 2 \mathrm{H}\right), 3.52\left(\mathrm{t},{ }^{3} J_{\mathrm{HH}}=6.6 \mathrm{~Hz}, 2 \mathrm{H}\right)$, 3.49-3.45 (m, 2H), 2.66-2.61 (m, 2H), 2.53-2.47 (m, 2H), $2.48(\mathrm{~s}, 3 \mathrm{H}) .{ }^{19} \mathrm{~F} \mathrm{NMR}\left(\mathrm{CDCl}_{3}, 282 \mathrm{MHz}\right) \delta:-223.36(\mathrm{tt}$, ${ }^{2} J_{\mathrm{HF}}=47.6 \mathrm{~Hz},{ }^{3} J_{\mathrm{HF}}=29.5 \mathrm{~Hz}$ ). HR-MS calcd. for $\mathrm{C}_{12} \mathrm{H}_{19} \mathrm{FN}_{3} \mathrm{OS}_{2}[\mathrm{M}+1]$ : 304.0948; found: 304.0950. EA calcd.: C 47.50, H 5.99, N 13.85; found: C 47.67, H 6.11, N 13.35 .

\section{3-(2-(2-(2-Fluoroethoxy)ethoxy)ethylthio)-4-(1-methyl- 1,2,5,6-tetrahydropyridin-3-yl)-1,2,5-thiadiazole (4c)}

Compound $\mathbf{4 c}$ was prepared in an analogous manner to that of 4a. Briefly, $150 \mathrm{mg}(0.3 \mathrm{mmol})$ of $3 \mathbf{c}$ was used in THF $(0.1 \mathrm{M})$ with 5 equiv. of TBAF. $4 \mathbf{c}$ was obtained in a 
$29 \%$ yield $(31 \mathrm{mg}) .{ }^{1} \mathrm{H}$ NMR $\left(\mathrm{CDCl}_{3}, 300 \mathrm{MHz}\right) \delta: 6.80-$ $6.75(\mathrm{~m}, 1 \mathrm{H}), 4.56\left(\mathrm{dm},{ }^{2} J_{\mathrm{HF}}=47.8 \mathrm{~Hz}, 2 \mathrm{H}\right), 3.87-3.79(\mathrm{~m}$, $3 \mathrm{H}), 3.73-3.68(\mathrm{~m}, 5 \mathrm{H}), 3.54-3.46(\mathrm{~m}, 4 \mathrm{H}), 2.68-2.62(\mathrm{~m}$, $2 \mathrm{H}), 2.54-2.47$ (m, 2H), $2.49(\mathrm{~s}, 3 \mathrm{H}) .{ }^{19} \mathrm{~F} \mathrm{NMR}\left(\mathrm{CDCl}_{3}\right.$, $282 \mathrm{MHz}) \delta:-223.31\left(\mathrm{tt},{ }^{2} J_{\mathrm{HF}}=47.9 \mathrm{~Hz},{ }^{3} J_{\mathrm{HF}}=29.6 \mathrm{~Hz}\right)$. HR-MS calcd. for $\mathrm{C}_{14} \mathrm{H}_{23} \mathrm{FN}_{3} \mathrm{O}_{2} \mathrm{~S}_{2}[\mathrm{M}+1]$ : 348.1210; found: 348.1212. EA calcd.: C 48.39, H 6.39, N 12.10; found: C 49.07, H 6.74, N 11.66.

\section{3-(Benzyloxy)propyl-4-methylbenzenesulfonate (6a)}

To an oven-dried round-bottomed flask under an atmosphere of $\mathrm{N}_{2}$ was added propane-1,3-diol (5a, $0.11 \mathrm{~mol}$ ), $1.4 \mathrm{~mL}(0.01 \mathrm{~mol})$ of benzyl bromide, and $\mathrm{KOH}$ (0.02 mol, neat). The reaction proceeded at $\mathrm{RT}$. Upon consumption of benzyl bromide (monitored by TLC, 40:60 EtOAc:Hex), the reaction mixture was diluted with $50 \mathrm{~mL}$ of $\mathrm{H}_{2} \mathrm{O}$ and washed with $\mathrm{CH}_{2} \mathrm{Cl}_{2}(50 \mathrm{~mL} \times 2)$. The combined organic layers were washed with $50 \mathrm{~mL}$ of brine, dried over $\mathrm{Na}_{2} \mathrm{SO}_{4}$, and concentrated. $\mathrm{CH}_{2} \mathrm{Cl}_{2}(50 \mathrm{~mL})$ was added and the mixture was cooled on ice. Triethylamine $(0.05 \mathrm{~mol})$ and DMAP (1 mol\%) were added. After $10 \mathrm{~min}$ of stirring, $0.03 \mathrm{~mol}$ of $\mathrm{TsCl}$ was added and the reaction proceeded until completion, as monitored by TLC (40:60 EtOAc:Hex). The mixture was then cooled on ice, diluted with $100 \mathrm{~mL}$ $\mathrm{H}_{2} \mathrm{O}$, and washed with dichloromethane $(100 \mathrm{~mL} \times 2)$. The combined organic layers were washed with $100 \mathrm{~mL}$ of brine, dried over $\mathrm{Na}_{2} \mathrm{SO}_{4}$, and concentrated. The final product was purified by flash chromatography (40:60 EtOAc:Hex) to yield $2.40 \mathrm{~g}$ of $\mathbf{6 a}(75 \%)$. ${ }^{1} \mathrm{H}$ NMR $\left(\mathrm{CDCl}_{3}, 300 \mathrm{MHz}\right) \delta$ : 7.81-7.76 (m, 2H), 7.35-7.22 (m, 7H), $4.40(\mathrm{~s}, 2 \mathrm{H}), 4.17(\mathrm{t}$, $\left.{ }^{3} J_{\mathrm{HH}}=6.3 \mathrm{~Hz}, 2 \mathrm{H}\right), 3.50\left(\mathrm{t},{ }^{3} J_{\mathrm{HH}}=5.8,2 \mathrm{H}\right), 2.42(\mathrm{~s}, 3 \mathrm{H})$, $1.98-1.90\left(\mathrm{q},{ }^{3} J_{\mathrm{HH}}=6.0 \mathrm{~Hz}, 2 \mathrm{H}\right)$.

\section{5-(Benzyloxy)pentyl-4-methylbenzenesulfonate (6b)}

Compound $\mathbf{6 b}$ was prepared in an analogous manner to that of 6a. Briefly, $0.07 \mathrm{~mol}$ of pentane-1,5-diol (5b), $0.02 \mathrm{~mol}$ of benzyl bromide, and $0.055 \mathrm{~mol}$ of $\mathrm{KOH}$ were used. Following the workup of the reaction mixture, $10 \mathrm{~mL}$ of dichloromethane, $0.07 \mathrm{~mol}$ of triethylamine, catalytic DMAP (1 mol\%), and $0.035 \mathrm{~mol}$ of $\mathrm{TsCl}$ were reacted and purified (vide supra). Compound $\mathbf{6 b}$ was obtained in a $65 \%$ yield $(4.54 \mathrm{~g}) .{ }^{1} \mathrm{H} \mathrm{NMR}\left(\mathrm{CDCl}_{3}, 300 \mathrm{MHz}\right) \delta: 7.81-7.76(\mathrm{~m}$, $2 \mathrm{H}), 7.36-7.26(\mathrm{~m}, 7 \mathrm{H}), 4.47(\mathrm{~s}, 2 \mathrm{H}), 4.02\left(\mathrm{t},{ }^{3} J_{\mathrm{HH}}=6.3 \mathrm{~Hz}\right.$, $2 \mathrm{H}), 3.42\left(\mathrm{t},{ }^{3} \mathrm{~J}_{\mathrm{HH}}=6.6 \mathrm{~Hz}, 2 \mathrm{H}\right), 2.44(\mathrm{~s}, 3 \mathrm{H}), 1.71-1.61(\mathrm{~m}$, 2H), 1.60-1.51 (m, 2H), 1.46-1.36 (m, 2H).

\section{6-(Benzyloxy)hexyl-4-methylbenzenesulfonate (6c)}

Compound $\mathbf{6 c}$ was prepared in an analogous manner to that of 6a. Briefly, $0.06 \mathrm{~mol}$ of hexane-1,6-diol (5c), $0.02 \mathrm{~mol}$ of benzyl bromide, and $0.055 \mathrm{~mol}$ of $\mathrm{KOH}$ were used. Following the workup, $10 \mathrm{~mL}$ of dichloromethane, $0.07 \mathrm{~mol}$ of triethylamine, DMAP (1 mol\%), and $0.04 \mathrm{~mol}$ of $\mathrm{TsCl}$ were reacted and purified (vide supra). Compound 6c was obtained in a $61 \%$ yield $(4.40 \mathrm{~g}) .{ }^{1} \mathrm{H} \mathrm{NMR}\left(\mathrm{CDCl}_{3}\right.$, $300 \mathrm{MHz}) \delta: 7.81-7.76(\mathrm{~m}, 2 \mathrm{H}), 7.36-7.28(\mathrm{~m}, 7 \mathrm{H}), 4.48(\mathrm{~s}$, $2 \mathrm{H}), 4.01\left(\mathrm{t},{ }^{3} J_{\mathrm{HH}}=6.6 \mathrm{~Hz}, 2 \mathrm{H}\right), 3.43\left(\mathrm{t},{ }^{3} J_{\mathrm{HH}}=6.6 \mathrm{~Hz}\right.$, $2 \mathrm{H}), 2.44(\mathrm{~s}, 3 \mathrm{H}) 1.67-1.51(\mathrm{~m}, 4 \mathrm{H}), 1.35-1.28(\mathrm{~m}, 4 \mathrm{H})$.

\section{7-(Benzyloxy)heptyl-4-methylbenzenesulfonate (6d)}

Compound 6d was prepared in an analogous manner to that of 6a. Briefly, $0.02 \mathrm{~mol}$ of hexane-1,6-diol (5d), $0.008 \mathrm{~mol}$ of benzyl bromide, and $0.015 \mathrm{~mol}$ of $\mathrm{KOH}$ were used. After workup, $8 \mathrm{~mL}$ of $\mathrm{CH}_{2} \mathrm{Cl}_{2}, 0.025 \mathrm{~mol}$ of triethylamine, DMAP (1 mol\%), and $0.02 \mathrm{~mol}$ of $\mathrm{TsCl}$ were reacted and purified (vide supra). 6d was obtained in a $69 \%$ yield (2.06 g). ${ }^{1} \mathrm{H} \mathrm{NMR}\left(\mathrm{CDCl}_{3}, 300 \mathrm{MHz}\right) \delta: 7.81-7.76(\mathrm{~m}, 2 \mathrm{H})$, $7.36-7.25(\mathrm{~m}, 7 \mathrm{H}), 4.49(\mathrm{~s}, 2 \mathrm{H}), 4.01\left(\mathrm{t},{ }^{3} J_{\mathrm{HH}}=6.4 \mathrm{~Hz}, 2 \mathrm{H}\right)$, $3.44\left(\mathrm{t},{ }^{3} \mathrm{~J}_{\mathrm{HH}}=6.7 \mathrm{~Hz}, 2 \mathrm{H}\right), 2.44(\mathrm{~s}, 3 \mathrm{H}), 1.66-1.51(\mathrm{~m}, 4 \mathrm{H})$, $1.36-1.20(\mathrm{~m}, 6 \mathrm{H})$.

\section{2-(2-(Benzyloxy)ethoxy)ethyl-4-methylbenzenesulfonate} (6e)

Compound 6e was prepared in an analogous manner to that of 6a. Diethyleneglycol (5e; $0.03 \mathrm{~mol}), 0.008 \mathrm{~mol}$ of benzyl bromide, and $0.03 \mathrm{~mol}$ of $\mathrm{KOH}$ were used. After workup, $20 \mathrm{~mL}$ of dichloromethane, $0.02 \mathrm{~mol}$ of triethylamine, DMAP (1 mol\%), and $0.07 \mathrm{~mol}$ of $\mathrm{TsCl}$ were reacted and purified (vide supra). Compound $\mathbf{6 e}$ was obtained in a $43 \%$ yield $(1.24 \mathrm{~g}) .{ }^{1} \mathrm{H}$ NMR $\left(\mathrm{CDCl}_{3}, 300 \mathrm{MHz}\right) \delta: 7.81-$ $7.76(\mathrm{~m}, 2 \mathrm{H}), 7.35-7.26(\mathrm{~m}, 7 \mathrm{H}), 4.53(\mathrm{~s}, 2 \mathrm{H}), 4.19-4.14$ $(\mathrm{m}, 2 \mathrm{H}), 3.72-3.67(\mathrm{~m}, 2 \mathrm{H}), 3.63-3.59(\mathrm{~m}, 2 \mathrm{H}), 3.58-3.54$ (m, 2H), 2.42 (s, 3H).

\section{2-(2-(2-(Benzyloxy)ethoxy)ethoxy)ethyl-4- methylbenzenesulfonate (6f)}

Compound $\mathbf{6 f}$ was prepared in an analogous manner to that of 6a. Briefly, $0.04 \mathrm{~mol}$ of diethyleneglycol (5f), $0.01 \mathrm{~mol}$ of benzyl bromide, and $0.04 \mathrm{~mol}$ of $\mathrm{KOH}$ were used. Following the workup, $20 \mathrm{~mL}$ of dichloromethane, $0.02 \mathrm{~mol}$ of triethylamine, DMAP ( $1 \mathrm{~mol} \%)$, and $0.06 \mathrm{~mol}$ of $\mathrm{TsCl}$ were reacted and purified (vide supra). Compound 6f was obtained in a $35 \%$ yield $(1.40 \mathrm{~g}) .{ }^{1} \mathrm{H} \mathrm{NMR}\left(\mathrm{CDCl}_{3}\right.$, $300 \mathrm{MHz}) \delta: 7.81-7.76(\mathrm{~m}, 2 \mathrm{H}), 7.35-7.26(\mathrm{~m}, 7 \mathrm{H}), 4.55(\mathrm{~s}$, $2 \mathrm{H})$, 4.17-4.12 (m, 2H), 3.70-3.66 (m, 2H), 3.65-3.60 (m, 4H), 3.59 (s, 4H), 3.04 (s, 3H).

\section{((3-Fluoropropoxy)methyl)benzene (7a)}

To a glass vial (Biotage) under an atmosphere of $\mathrm{N}_{2}$ containing $0.02 \mathrm{~mol}$ of TBAF (dried under reduced pressure overnight) was added $20 \mathrm{~mL}$ of freshly distilled THF followed by $500 \mathrm{mg}(1.6 \mathrm{mmol})$ of $\mathbf{6 a}$. The reaction was sealed and microwave heated for $1 \mathrm{~h}$ at $160{ }^{\circ} \mathrm{C}$. THF was removed under reduced pressure and the resulting product was dissolved in $50 \mathrm{~mL}$ of EtOAc and washed with $50 \mathrm{~mL}$ of $\mathrm{H}_{2} \mathrm{O}$. The aqueous layer was washed a second time with $50 \mathrm{~mL}$ of EtOAc and the combined organic layers were washed with $50 \mathrm{~mL}$ of brine, dried over $\mathrm{Na}_{2} \mathrm{SO}_{4}$, and concentrated. The product was purified by flash chromatography (30:70 EtOAc:Hex $(v / v))$ to yield $179 \mathrm{mg}$ of $7 \mathbf{a}(68 \%) .{ }^{1} \mathrm{H}$ NMR $\left(\mathrm{CDCl}_{3}, 400 \mathrm{MHz}\right) \delta: 7.37-7.25(\mathrm{~m}, 5 \mathrm{H}), 4.56\left(\mathrm{dt},{ }^{2} J_{\mathrm{HF}}=\right.$ $\left.47.1 \mathrm{~Hz},{ }^{3} J_{\mathrm{HH}}=6.0 \mathrm{~Hz}, 2 \mathrm{H}\right), 4.51(\mathrm{~s}, 2 \mathrm{H}), 3.60\left(\mathrm{t},{ }^{3} J_{\mathrm{HH}}=\right.$ $6.2 \mathrm{~Hz}, 2 \mathrm{H}), 1.99\left(\mathrm{dm},{ }^{3} J_{\mathrm{HF}}=25.8 \mathrm{~Hz}, 2 \mathrm{H}\right) .{ }^{19} \mathrm{~F} \mathrm{NMR}$ $\left(\mathrm{CDCl}_{3}, 376 \mathrm{MHz}\right) \delta:-222.05\left(\mathrm{tt},{ }^{2} J_{\mathrm{HF}}=47.0 \mathrm{~Hz},{ }^{3} J_{\mathrm{HF}}=\right.$ $25.7 \mathrm{~Hz})$.

\section{((5-Fluoropentyloxy)methyl)benzene (7b)}

Compound $\mathbf{7 b}$ was prepared in an analogous manner to that of 7a, where $0.02 \mathrm{~mol}$ of TBAF and $1.4 \mathrm{mmol}$ of $\mathbf{6 b}$ were used in $20 \mathrm{~mL}$ of THF. Compound $\mathbf{7 b}$ was obtained in a $70 \%$ yield $(198 \mathrm{mg}) .{ }^{1} \mathrm{H} \mathrm{NMR}\left(\mathrm{CDCl}_{3}, 400 \mathrm{MHz}\right) \delta: 7.35-$ $7.25(\mathrm{~m}, 5 \mathrm{H}), 4.50(\mathrm{~s}, 2 \mathrm{H}), 4.43\left(\mathrm{dt},{ }^{2} J_{\mathrm{HF}}=47.4 \mathrm{~Hz},{ }^{3} J_{\mathrm{HH}}=\right.$ $6.1 \mathrm{~Hz}, 2 \mathrm{H}), 3.48\left(\mathrm{t},{ }^{3} J_{\mathrm{HH}}=6.5 \mathrm{~Hz}, 2 \mathrm{H}\right), 1.78-1.62(\mathrm{~m}, 4 \mathrm{H})$, 1.54-1.45 (m, 2H). ${ }^{19} \mathrm{~F}$ NMR $\left(\mathrm{CDCl}_{3}, 376 \mathrm{MHz}\right) \delta:-218.66$ $\left(\mathrm{tt},{ }^{2} J_{\mathrm{HF}}=47.4 \mathrm{~Hz},{ }^{3} J_{\mathrm{HF}}=24.8 \mathrm{~Hz}\right)$. 


\section{((6-Fluorohexyloxy)methyl)benzene (7c)}

Compound 7c was prepared in an analogous manner to that of $7 \mathbf{a}$, where $0.02 \mathrm{~mol}$ of TBAF and $1.4 \mathrm{mmol}$ of $\mathbf{6 c}$ were used in $20 \mathrm{~mL}$ of THF. Compound $7 \mathrm{c}$ was obtained in a $72 \%$ yield $(209 \mathrm{mg}) .{ }^{1} \mathrm{H} \mathrm{NMR}\left(\mathrm{CDCl}_{3}, 400 \mathrm{MHz}\right) \delta: 7.35-$ $7.24(\mathrm{~m}, 5 \mathrm{H}), 4.50(\mathrm{~s}, 2 \mathrm{H}), 4.42\left(\mathrm{dt},{ }^{2} J_{\mathrm{HF}}=47.4 \mathrm{~Hz},{ }^{3} J_{\mathrm{HH}}=\right.$ $6.2 \mathrm{~Hz}, 2 \mathrm{H}), 3.47\left(\mathrm{t},{ }^{3} J_{\mathrm{HH}}=6.6 \mathrm{~Hz}, 2 \mathrm{H}\right), 1.76-1.59(\mathrm{~m}, 4 \mathrm{H})$, $1.45-1.39(\mathrm{~m}, 4 \mathrm{H}) .{ }^{19} \mathrm{~F} \mathrm{NMR}\left(\mathrm{CDCl}_{3}, 376 \mathrm{MHz}\right) \delta:-218.55$ $\left(\mathrm{tt},{ }^{2} J_{\mathrm{HF}}=47.3 \mathrm{~Hz},{ }^{3} J_{\mathrm{HF}}=24.9 \mathrm{~Hz}\right)$.

\section{((7-Fluoroheptyloxy)methyl)benzene (7d)}

Compound $\mathbf{7 d}$ was prepared in an analogous manner to that of $7 \mathbf{a}$, where $0.02 \mathrm{~mol}$ of TBAF and $1.3 \mathrm{mmol}$ of $\mathbf{6 d}$ were used in $20 \mathrm{~mL}$ of THF. Compound 7d was obtained in an $85 \%$ yield $(251 \mathrm{mg}) .{ }^{1} \mathrm{H}$ NMR $\left(\mathrm{CDCl}_{3}, 400 \mathrm{MHz}\right) \delta$ : 7.35-7.24 (m, 5H), $4.50(\mathrm{~s}, 2 \mathrm{H}), 4.42\left(\mathrm{dt},{ }^{2} J_{\mathrm{HF}}=47.5 \mathrm{~Hz}\right.$, $\left.{ }^{3} J_{\mathrm{HH}}=6.1 \mathrm{~Hz}, 2 \mathrm{H}\right), 3.46\left(\mathrm{t},{ }^{3} J_{\mathrm{HH}}=6.6 \mathrm{~Hz}, 2 \mathrm{H}\right), 1.75-1.58$ $(\mathrm{m}, 4 \mathrm{H}), 1.45-1.30(\mathrm{~m}, 6 \mathrm{H}) .{ }^{19} \mathrm{~F} \mathrm{NMR}\left(\mathrm{CDCl}_{3}, 376 \mathrm{MHz}\right)$ $\delta:-218.46\left(\mathrm{tt},{ }^{2} J_{\mathrm{HF}}=47.5 \mathrm{~Hz},{ }^{3} J_{\mathrm{HF}}=24.9 \mathrm{~Hz}\right)$.

\section{((2-(2-Fluoroethoxy)ethoxy)methyl)benzene (7e)}

Compound 7e was prepared in an analogous manner to that of $7 \mathbf{a}$, where $0.02 \mathrm{~mol}$ of TBAF and $1.4 \mathrm{mmol}$ of $\mathbf{6 e}$ were used in $20 \mathrm{~mL}$ of THF. Compound 7e was obtained in a $91 \%$ yield $(252 \mathrm{mg}) .{ }^{1} \mathrm{H} \mathrm{NMR}\left(\mathrm{CDCl}_{3}, 400 \mathrm{MHz}\right) \delta: 7.36-$ $7.25(\mathrm{~m}, 5 \mathrm{H}), 4.58(\mathrm{~s}, 2 \mathrm{H}), 4.56\left(\mathrm{dm},{ }^{2} J_{\mathrm{HF}}=47.7 \mathrm{~Hz}, 2 \mathrm{H}\right)$, 3.80-3.78 (m, 1H), 3.73-3.69 (m, 3H), 3.67-3.63 (m, 2H). ${ }^{19} \mathrm{~F} \mathrm{NMR}\left(\mathrm{CDCl}_{3}, 376 \mathrm{MHz}\right) \delta:-223.27\left(\mathrm{tt},{ }^{2} J_{\mathrm{HF}}=47.7 \mathrm{~Hz}\right.$, $\left.{ }^{3} J_{\mathrm{HF}}=29.4 \mathrm{~Hz}\right)$.

\section{((2-(2-(2-Fluoroethoxy)ethoxy)ethoxy)methyl)benzene (7f)}

Compound 7f was prepared in an analogous manner to that of $7 \mathbf{a}$, where $0.02 \mathrm{~mol}$ of TBAF and $1.3 \mathrm{mmol}$ of $\mathbf{6 f}$ were used in $20 \mathrm{~mL}$ of THF. Compound $7 \mathbf{f}$ was obtained in a $90 \%$ yield $(273 \mathrm{mg}) .{ }^{1} \mathrm{H} \mathrm{NMR}\left(\mathrm{CDCl}_{3}, 400 \mathrm{MHz}\right) \delta: 7.36-$ $7.26(\mathrm{~m}, 5 \mathrm{H}), 4.57(\mathrm{~s}, 2 \mathrm{H}), 4.55\left(\mathrm{dm},{ }^{2} J_{\mathrm{HF}}=47.6 \mathrm{~Hz}, 2 \mathrm{H}\right)$, 3.80-3.77 (m, 1H), 3.72-3.67 (m, 7H), 3.66-3.62 (m, 2H). ${ }^{19} \mathrm{~F} \mathrm{NMR}\left(\mathrm{CDCl}_{3}, 376 \mathrm{MHz}\right) \delta:-223.34\left(\mathrm{tt},{ }^{2} J_{\mathrm{HF}}=47.7 \mathrm{~Hz}\right.$, $\left.{ }^{3} J_{\mathrm{HF}}=29.8 \mathrm{~Hz}\right)$.

\section{3-(4-(1-Methyl-1,2,5,6-tetrahydropyridin-3-yl)-1,2,5- thiadiazol-3-yloxy)propan-1-ol (8a)}

To an oven-dried round-bottomed flask under an atmosphere of $\mathrm{N}_{2}, 1.16 \mathrm{mmol}$ of propane-1,3-diol (5a) was added to $2.5 \mathrm{~mL}$ of freshly distilled THF. To the reaction mixture was added $0.92 \mathrm{mmol}$ of $60 \% \mathrm{NaH}$, and the mixture was stirred at RT for $30 \mathrm{~min}$. Compound 1 (0.23 mmol) was added and the reaction was refluxed overnight. The reaction mixture was diluted with $30 \mathrm{~mL}$ of $\mathrm{H}_{2} \mathrm{O}$ and washed with $30 \mathrm{~mL}$ of $\mathrm{CH}_{2} \mathrm{Cl}_{2}(\times 2)$. The combined organic layers were then washed with $40 \mathrm{~mL}$ of brine, dried over $\mathrm{Na}_{2} \mathrm{SO}_{4}$, and concentrated. The product was purified by PTLC (30:70 EtOAc:Hex $(v / v))$ and $8 \mathbf{a}$ was obtained in a yield of $25.2 \mathrm{mg}(43 \%) .{ }^{1} \mathrm{H} \mathrm{NMR}\left(\mathrm{CDCl}_{3}, 400 \mathrm{MHz}\right) \delta: 7.04-7.00$ $(\mathrm{m}, 1 \mathrm{H}), 4.59(\mathrm{t}, J=6.1 \mathrm{~Hz}, 2 \mathrm{H}), 3.78(\mathrm{t}, J=6.1 \mathrm{~Hz}, 2 \mathrm{H})$, 3.46-3.44 (m, 2H), 2.60-2.56 (m, 2H), 2.47-2.42 (m, 2H), $2.46(\mathrm{~s}, 3 \mathrm{H}), 2.11-2.04(\mathrm{~m}, 2 \mathrm{H})$. HR-MS calcd. for $\mathrm{C}_{11} \mathrm{H}_{18} \mathrm{~N}_{3} \mathrm{O}_{2} \mathrm{~S}[\mathrm{M}+1]$ : 256.1114; found: 256.1112. EA calcd.: C 51.74, H 6.71, N 16.46; found: C 51.72, H 6.73, N 16.06 .
4-(4-(1-Methyl-1,2,5,6-tetrahydropyridin-3-yl)-1,2,5thiadiazol-3-yloxy)butan-1-ol (8b)

Compound $\mathbf{8 b}$ was prepared in an analogous manner to that of $\mathbf{8 a}$, where $1.15 \mathrm{mmol}$ of butane-1,4-diol $(\mathbf{5 b})$, $0.92 \mathrm{mmol}$ of $60 \% \mathrm{NaH}$, and $0.23 \mathrm{mmol}$ of 1 in $2.5 \mathrm{~mL}$ of freshly distilled THF were used. Compound $\mathbf{8 b}$ was obtained in a $48 \%$ yield $(30 \mathrm{mg}) .{ }^{1} \mathrm{H}$ NMR $\left(\mathrm{CDCl}_{3}, 300 \mathrm{MHz}\right) \delta$ : 7.07-7.02 $(\mathrm{m}, 1 \mathrm{H}), 4.48\left(\mathrm{t},{ }^{3} J_{\mathrm{HH}}=4.46 \mathrm{~Hz}, 2 \mathrm{H}\right), 3.71(\mathrm{t}$, $\left.{ }^{3} J_{\mathrm{HH}}=6.44 \mathrm{~Hz}, 2 \mathrm{H}\right), 3.47-3.42(\mathrm{~m}, 2 \mathrm{H}), 2.61-2.55(\mathrm{~m}$, $2 \mathrm{H}), 2.48-2.41(\mathrm{~m}, 2 \mathrm{H}), 2.46(\mathrm{~s}, 3 \mathrm{H}), 2.00-1.89(\mathrm{~m}, 2 \mathrm{H})$, 1.78-1.67 (m, 2H). HR-MS calcd. for $\mathrm{C}_{12} \mathrm{H}_{20} \mathrm{~N}_{3} \mathrm{O}_{2} \mathrm{~S}[\mathrm{M}+$ 1]: 270.1271; found: 270.1269. EA calcd.: C 53.51, H 7.11, N 15.60; found: C 52.56, H 6.85, N 15.49.

\section{5-(4-(1-Methyl-1,2,5,6-tetrahydropyridin-3-yl)-1,2,5- thiadiazol-3-yloxy)pentan-1-ol (8c)}

Compound 8c was prepared in an analogous manner to that of $\mathbf{8 a}$, where $1.15 \mathrm{mmol}$ of pentane-1,5-diol $(\mathbf{5 c})$, $0.92 \mathrm{mmol}$ of $60 \% \mathrm{NaH}$, and $0.23 \mathrm{mmol}$ of 1 in $2.5 \mathrm{~mL}$ of freshly distilled THF were used. Compound $\mathbf{8 c}$ was obtained in a $34 \%$ yield $(22 \mathrm{mg}) .{ }^{1} \mathrm{H}$ NMR $\left(\mathrm{CDCl}_{3}, 300 \mathrm{MHz}\right) \delta$ : 7.07-7.02 (m, 1H), $4.47\left(\mathrm{t},{ }^{3} J_{\mathrm{HH}}=6.54 \mathrm{~Hz}, 2 \mathrm{H}\right), 3.69(\mathrm{t}$, $\left.{ }^{3} J_{\mathrm{HH}}=6.42 \mathrm{~Hz}, 2 \mathrm{H}\right), 3.48-3.43(\mathrm{~m}, 2 \mathrm{H}), 2.61-2.55(\mathrm{~m}$, $2 \mathrm{H}), 2.49-2.42(\mathrm{~m}, 2 \mathrm{H}), 2.47(\mathrm{~s}, 3 \mathrm{H}), 1.95-1.83(\mathrm{~m}, 2 \mathrm{H})$, 1.70-1.51 (m, 4H). HR-MS calcd. for $\mathrm{C}_{13} \mathrm{H}_{22} \mathrm{~N}_{3} \mathrm{O}_{2} \mathrm{~S}[\mathrm{M}+$ 1]: 284.1427; found: 284.1425. EA calcd.: C 55.10, H 7.47, N 14.83; found: C 58.85, H 7.07, N 14.82.

\section{6-(4-(1-Methyl-1,2,5,6-tetrahydropyridin-3-yl)-1,2,5- thiadiazol-3-yloxy)hexan-1-ol (8d)}

Compound 8d was prepared in an analogous manner to that of $\mathbf{8 a}$, where $1.15 \mathrm{mmol}$ of hexane-1,6-diol (5d), $0.92 \mathrm{mmol}$ of $\mathrm{NaH}(60 \%$ in mineral oil), and $0.23 \mathrm{mmol}$ of 1 in $2.5 \mathrm{~mL}$ of freshly distilled THF were used. Compound 8d was obtained in a $25 \%$ yield $(17 \mathrm{mg}) .{ }^{1} \mathrm{H} \mathrm{NMR}\left(\mathrm{CDCl}_{3}\right.$, $300 \mathrm{MHz}) \delta: 7.07-7.01(\mathrm{~m}, 1 \mathrm{H}), 4.49-4.41(\mathrm{~m}, 2 \mathrm{H}), 3.67-$ $3.60(\mathrm{~m}, 2 \mathrm{H}), 3.48-3.40(\mathrm{~m}, 2 \mathrm{H}), 2.62-2.55(\mathrm{~m}, 2 \mathrm{H}), 2.51-$ $2.42(\mathrm{~m}, 2 \mathrm{H}), 2.47$ (s, 3H), 2.14 (br, 1H), 1.91-1.80 (m, 2H), 1.65-1.54 (m, 2H), 1.53-1.39 (m, 4H). HR-MS calcd. for $\mathrm{C}_{14} \mathrm{H}_{24} \mathrm{~N}_{3} \mathrm{O}_{2} \mathrm{~S}[\mathrm{M}+1]$ : 298.1584; found: 298.1582. EA calcd.: C 56.54, H 7.79, N 13.75; found: C 55.02, H 7.42, N 13.75 .

\section{2-(2-(4-(1-Methyl-1,2,5,6-tetrahydropyridin-3-yl)-1,2,5- thiadiazol-3-yloxy)ethoxy)ethanol (8e)}

Compound 8e was prepared in an analogous manner to that of 8a, where $0.084 \mathrm{mmol}$ of diethyleneglycol (5e), $0.42 \mathrm{mmol}$ of $60 \% \mathrm{NaH}$, and $0.46 \mathrm{mmol}$ of 1 in $3 \mathrm{~mL}$ of freshly distilled THF were used. Compound $8 \mathbf{e}$ was obtained in a $74 \%$ yield $(89 \mathrm{mg}) .{ }^{1} \mathrm{H} \mathrm{NMR}\left(\mathrm{CDCl}_{3}, 400 \mathrm{MHz}\right) \delta$ : 7.08-7.04 (m, 1H), 4.64-4.60 (m, 2H), 3.92-3.89 (m, 2H), 3.76-3.73 (m, 2H), 3.67-3.63 (m, 2H), 3.46-3.43 (m, 2H), 2.59-2.55 (m, 2H), 2.47-2.42 (m, 2H), 2.45 (s, 3H). HRMS calcd. for $\mathrm{C}_{12} \mathrm{H}_{20} \mathrm{~N}_{3} \mathrm{O}_{3} \mathrm{~S}[\mathrm{M}+1]$ : 286.1220; found: 286.1218. EA calcd.: C 50.50, H 6.72, N 14.73; found: C 49.91, H 6.70, N 14.37.

\section{2-(2-(2-(4-(1-Methyl-1,2,5,6-tetrahydropyridin-3-yl)-1,2,5- thiadiazol-3-yloxy)ethoxy)ethoxy)ethanol (8f)}

Compound 8f was prepared in an analogous manner to that of $\mathbf{8 a}$, where $0.084 \mathrm{mmol}$ of diethyleneglycol (5f), $0.42 \mathrm{mmol}$ of $60 \% \mathrm{NaH}$, and $0.46 \mathrm{mmol}$ of 1 in $3.0 \mathrm{~mL}$ of 
freshly distilled THF were used. 8f was obtained in a $65 \%$ yield $(81 \mathrm{mg}) .{ }^{1} \mathrm{H}$ NMR $\left(\mathrm{CDCl}_{3}, 400 \mathrm{MHz}\right) \delta$ : 6.77-6.73 (m, 1H), 3.85-3.80 (m, 2H), 3.75-3.71 (m, 2H), 3.69-3.66 (m, 4H), 3.63-3.59 (m, 2H), 3.53-3.49 (m, 2H), 3.45-3.42 (m, 2H), 2.63-2.58 (m, 2H), 2.51-2.45 (m, 2H), $2.42(\mathrm{~s}$, $3 \mathrm{H})$. HR-MS: calcd. for $\mathrm{C}_{14} \mathrm{H}_{24} \mathrm{~N}_{3} \mathrm{O}_{4} \mathrm{~S}[\mathrm{M}+1]$ : 330.1482; found: 330.1476. EA calcd.: C 51.04, H 7.04, N 12.76; found: C 50.07, H 6.89, N 12.52.

\section{3-(3-Fluoropropoxy)-4-(1-methyl-1,2,5,6-tetrahydropyridin- 3-yl)-1,2,5-thiadiazole (9a)}

To an oven-dried round-bottomed flask under an atmosphere of $\mathrm{N}_{2}$ containing $3 \mathrm{~mL}$ of freshly distilled THF was added $0.5 \mathrm{mmol}$ of $7 \mathbf{a}$ followed by $10 \mathrm{mg}$ each of $\mathrm{Pd} / \mathrm{C}$ and $\mathrm{Pd}(\mathrm{OH})_{2}$. The reaction vessel was purged with $\mathrm{H}_{2}(\mathrm{~g})$ and maintained under an atmosphere of $\mathrm{H}_{2}(\mathrm{~g})$ for $2 \mathrm{~h}$ while stirring vigorously. Upon consumption of the starting material as monitored by TLC (60:40 EtOAc:Hex $(v / v))$, the reaction mixture was purged with $\mathrm{N}_{2}$ and cooled in an ice bath, and $1.0 \mathrm{mmol}$ of $\mathrm{NaH}(60 \%$ in mineral oil) was added. The mixture was stirred for $30 \mathrm{~min}$ at RT followed by the addition of $0.2 \mathrm{mmol}$ of $\mathbf{1}$. The reaction mixture was subsequently refluxed overnight. Upon consumption of the starting material, the reaction was filtered through celite and the THF was removed under reduced pressure. The product was dissolved in $30 \mathrm{~mL}$ of $\mathrm{CH}_{2} \mathrm{Cl}_{2}$ and washed with $30 \mathrm{~mL}$ of $\mathrm{H}_{2} \mathrm{O}$, and the aqueous layer was further extracted with $30 \mathrm{~mL}$ of $\mathrm{CH}_{2} \mathrm{Cl}_{2}$. The combined organic layers were washed with $30 \mathrm{~mL}$ of brine, dried over $\mathrm{Na}_{2} \mathrm{SO}_{4}$, and concentrated. The product was purified by PTLC $(60: 40$ EtOAc:Hex $(v / v))$ to yield $21 \mathrm{mg}$ 9a $(41 \%)$. ${ }^{1} \mathrm{H}$ NMR $\left(\mathrm{CDCl}_{3}, 400 \mathrm{MHz}\right) \delta$ : 7.04-6.99 (m, 1H), $4.63\left(\mathrm{dm},{ }^{2} J_{\mathrm{HF}}=47.0 \mathrm{~Hz}, 2 \mathrm{H}\right), 4.61(\mathrm{t}$, $\left.{ }^{3} J_{\mathrm{HH}}=6.2 \mathrm{~Hz}, 2 \mathrm{H}\right), 3.47-3.43(\mathrm{~m}, 2 \mathrm{H}), 2.60-2.55(\mathrm{~m}, 2 \mathrm{H})$, 2.48-2.42 (m, 2H), $2.46(\mathrm{~s}, 3 \mathrm{H}), 2.25\left(\mathrm{dm},{ }^{3} J_{\mathrm{HF}}=25.6 \mathrm{~Hz}\right.$, $2 \mathrm{H}) .{ }^{19} \mathrm{~F} \mathrm{NMR}\left(\mathrm{CDCl}_{3}, 376 \mathrm{MHz}\right) \delta:-222.38\left(\mathrm{tt},{ }^{2} J_{\mathrm{HF}}=\right.$ $\left.47.0 \mathrm{~Hz},{ }^{3} J_{\mathrm{HF}}=25.8 \mathrm{~Hz}\right)$. HR-MS calcd. for $\mathrm{C}_{11} \mathrm{H}_{17} \mathrm{FN}_{3} \mathrm{OS}$ $[\mathrm{M}+1]$ : 258.1071; found: 258.1068. EA calcd.: C 51.34, H 6.27, N 16.33; found: C 51.64, H 6.27, N 15.84.

\section{3-(5-Fluoropentyloxy)-4-(1-methyl-1,2,5,6- tetrahydropyridin-3-yl)-1,2,5-thiadiazole (9b)}

Compound $\mathbf{9 b}$ was prepared in an analogous manner to that of $\mathbf{9 a}$, where $0.4 \mathrm{mmol}$ of $\mathbf{7 b}$ was used followed by $1.4 \mathrm{mmol}$ of $60 \% \mathrm{NaH}$ and $0.23 \mathrm{mmol}$ of $\mathbf{1}$. Compound $\mathbf{9 b}$ was obtained in a $29 \%$ yield $(19 \mathrm{mg}) .{ }^{1} \mathrm{H} \mathrm{NMR}\left(\mathrm{CDCl}_{3}\right.$, $400 \mathrm{MHz}) \delta$ : 7.07-7.03 (m, 1H), $4.48\left(\mathrm{dt},{ }^{2} J_{\mathrm{HF}}=46.9 \mathrm{~Hz}\right.$, $\left.{ }^{3} J_{\mathrm{HH}}=6.1 \mathrm{~Hz}, 2 \mathrm{H}\right), 4.47\left(\mathrm{t},{ }^{3} J_{\mathrm{HH}}=6.5 \mathrm{~Hz}, 2 \mathrm{H}\right), 3.50-3.47$ $(\mathrm{m}, 2 \mathrm{H}), 2.64-2.59(\mathrm{~m}, 2 \mathrm{H}), 2.50-2.44(\mathrm{~m}, 2 \mathrm{H}), 2.49(\mathrm{~s}$, $3 \mathrm{H}), 1.94-1.86(\mathrm{~m}, 2 \mathrm{H}), 1.85-1.72(\mathrm{~m}, 2 \mathrm{H}), 1.64-1.56(\mathrm{~m}$, 2H). ${ }^{19} \mathrm{~F} \mathrm{NMR}\left(\mathrm{CDCl}_{3}, 376 \mathrm{MHz}\right) \delta:-219.18\left(\mathrm{tt},{ }^{2} J_{\mathrm{HF}}=\right.$ $47.1 \mathrm{~Hz},{ }^{3} J_{\mathrm{HF}}=25.4 \mathrm{~Hz}$ ). HR-MS calcd. for $\mathrm{C}_{13} \mathrm{H}_{21} \mathrm{FN}_{3} \mathrm{OS}$ $[\mathrm{M}+1]$ : 286.1384; found: 286.1380. EA calcd.: C 54.71, H 7.06, N 14.72; found: C 54.90, H 6.87, N 14.79.

\section{3-(6-Fluorohexyloxy)-4-(1-methyl-1,2,5,6- tetrahydropyridin-3-yl)-1,2,5-thiadiazole (9c)}

Compound 9c was prepared in an analogous manner to that of $9 \mathbf{a}$, where $0.4 \mathrm{mmol}$ of $\mathbf{7 c}$ was used followed by $1.4 \mathrm{mmol}$ of $60 \% \mathrm{NaH}$ and $0.23 \mathrm{mmol}$ of $\mathbf{1}$. Compound 9c was obtained in a $39 \%$ yield $(27 \mathrm{mg}) .{ }^{1} \mathrm{H} \mathrm{NMR}\left(\mathrm{CDCl}_{3}\right.$, $400 \mathrm{MHz}) \delta$ : 7.07-7.03 (m, 1H), $4.46\left(\mathrm{t},{ }^{3} J_{\mathrm{HH}}=6.9 \mathrm{~Hz}\right.$,
$2 \mathrm{H}), 4.46\left(\mathrm{dt},{ }^{2} J_{\mathrm{HF}}=47.2 \mathrm{~Hz},{ }^{3} J_{\mathrm{HH}}=6.0 \mathrm{~Hz}, 2 \mathrm{H}\right), 3.48-$ $3.45(\mathrm{~m}, 2 \mathrm{H}), 2.61-2.56(\mathrm{~m}, 2 \mathrm{H}), 2.48-2.43(\mathrm{~m}, 2 \mathrm{H}), 2.47$ $(\mathrm{s}, 3 \mathrm{H}), 1.90-1.83(\mathrm{~m}, 2 \mathrm{H}), 1.79-1.68(\mathrm{~m}, 2 \mathrm{H}), 1.53-148$ $(\mathrm{m}, 4 \mathrm{H}) .{ }^{19} \mathrm{~F} \mathrm{NMR}\left(\mathrm{CDCl}_{3}, 376 \mathrm{MHz}\right) \delta:-218.79\left(\mathrm{tt},{ }^{2} J_{\mathrm{HF}}=\right.$ $47.2 \mathrm{~Hz},{ }^{3} J_{\mathrm{HF}}=25.3 \mathrm{~Hz}$ ). HR-MS calcd. for $\mathrm{C}_{14} \mathrm{H}_{23} \mathrm{FN}_{3} \mathrm{OS}$ $[\mathrm{M}+1]$ : 300.1540; found: 300.1536. EA calcd.: C 56.16, H 7.41, N 14.03; found: C 56.58, H 7.39, N 13.77.

\section{3-(7-Fluoroheptyloxy)-4-(1-methyl-1,2,5,6-} tetrahydropyridin-3-yl)-1,2,5-thiadiazole (9d)

Compound 9d was prepared in an analogous manner to that of $9 \mathbf{a}$, where $0.4 \mathrm{mmol}$ of $\mathbf{7 d}$ was used followed by $1.4 \mathrm{mmol}$ of $60 \% \mathrm{NaH}$ and $0.23 \mathrm{mmol}$ of $\mathbf{1}$. Compound 9d was obtained in a $35 \%$ yield $(25 \mathrm{mg}) .{ }^{1} \mathrm{H} \mathrm{NMR}\left(\mathrm{CDCl}_{3}\right.$, $400 \mathrm{MHz}) \delta: 7.08-7.04(\mathrm{~m}, 2 \mathrm{H}), 4.45\left(\mathrm{t},{ }^{3} J_{\mathrm{HH}}=6.6 \mathrm{~Hz}\right.$, $2 \mathrm{H}), 4.45\left(\mathrm{dt},{ }^{2} J_{\mathrm{HF}}=47.6 \mathrm{~Hz},{ }^{3} J_{\mathrm{HH}}=6.2 \mathrm{~Hz}, 2 \mathrm{H}\right), 3.47-344$ (m, 2H), 2.61-2.56 (m, 2H), 2.48-2.43 (m, 2H), $2.47(\mathrm{~s}$, $3 \mathrm{H}), 1.89-1.81(\mathrm{~m}, 2 \mathrm{H}), 1.76-1.62(\mathrm{~m}, 2 \mathrm{H}), 1.51-1.40(\mathrm{~m}$, $5 \mathrm{H}) .{ }^{19} \mathrm{~F} \mathrm{NMR}\left(\mathrm{CDCl}_{3}, 376 \mathrm{MHz}\right) \delta:-218.62\left(\mathrm{tt},{ }^{2} J_{\mathrm{HF}}=\right.$ $\left.47.5 \mathrm{~Hz},{ }^{3} J_{\mathrm{HF}}=25.2 \mathrm{~Hz}\right)$. HR-MS calcd. for $\mathrm{C}_{15} \mathrm{H}_{25} \mathrm{FN}_{3} \mathrm{OS}$ $[\mathrm{M}+1]$ : 314.1697; found: 314.1693. EA calcd.: C 57.48, H 7.72, N 13.41; found: C 57.69, H 7.65, N 13.17.

\section{3-(2-(2-Fluoroethoxy)ethoxy)-4-(1-methyl-1,2,5,6- tetrahydropyridin-3-yl)-1,2,5-thiadiazole (9e)}

Compound 9e was prepared in an analogous manner to that of $9 \mathbf{a}$, where $0.4 \mathrm{mmol}$ of $7 \mathbf{e}$ was used followed by $1.4 \mathrm{mmol}$ of $60 \% \mathrm{NaH}$ and $0.23 \mathrm{mmol}$ of $\mathbf{1}$. Compound $9 \mathbf{e}$ was obtained in a $45 \%$ yield $(30 \mathrm{mg}) .{ }^{1} \mathrm{H} \mathrm{NMR}\left(\mathrm{CDCl}_{3}\right.$, $400 \mathrm{MHz}) \delta: 7.12-7.07(\mathrm{~m}, 1 \mathrm{H}), 4.64-4.61(\mathrm{~m}, 2 \mathrm{H}), 4.58$ $\left(\mathrm{dm},{ }^{2} J_{\mathrm{HF}}=47.6 \mathrm{~Hz}, 2 \mathrm{H}\right), 3.96-3.92(\mathrm{~m}, 2 \mathrm{H}), 3.79(\mathrm{dm}$, $\left.{ }^{3} J_{\mathrm{HF}}=29.4 \mathrm{~Hz}, 2 \mathrm{H}\right), 3.47-3.44(\mathrm{~m}, 2 \mathrm{H}), 2.60-2.55(\mathrm{~m}, 2 \mathrm{H})$, 2.49-2.43 (m, 2H), $2.46(\mathrm{~s}, 3 \mathrm{H}) .{ }^{19} \mathrm{~F}$ NMR $\left(\mathrm{CDCl}_{3}\right.$, $376 \mathrm{MHz}) \delta:-223.51\left(\mathrm{tt},{ }^{2} J_{\mathrm{HF}}=47.7 \mathrm{~Hz},{ }^{3} J_{\mathrm{HF}}=28.9 \mathrm{~Hz}\right)$. HR-MS calcd. for $\mathrm{C}_{12} \mathrm{H}_{19} \mathrm{FN}_{3} \mathrm{O}_{2} \mathrm{~S}[\mathrm{M}+1]$ : 288.1177; found: 288.1173. EA calcd.: C 50.16, H 6.361, N 14.62; found: C 50.25, H 6.44, N 14.40.

\section{3-(2-(2-(2-Fluoroethoxy)ethoxy)ethoxy)-4-(1-methyl- 1,2,5,6-tetrahydropyridin-3-yl)-1,2,5-thiadiazole (9f)}

Compound 9f was prepared in an analogous manner to that of 9a, where $0.4 \mathrm{mmol}$ of $\mathbf{7 f}$ was used followed by $1.4 \mathrm{mmol}$ of $60 \% \mathrm{NaH}$ and $0.23 \mathrm{mmol}$ of $\mathbf{1}$. Compound $9 \mathrm{f}$ was obtained in a $62 \%$ yield $(46 \mathrm{mg}) .{ }^{1} \mathrm{H}$ NMR $\left(\mathrm{CDCl}_{3}\right.$, $400 \mathrm{MHz}) \delta$ : 7.11-7.07 (m, 1H), 4.63-4.60 (m, 3H), 4.51$4.48(\mathrm{~m}, 1 \mathrm{H}), 3.93-3.90(\mathrm{~m}, 2 \mathrm{H}), 3.79-3.77(\mathrm{~m}, 1 \mathrm{H}), 3.74$ $3.68(\mathrm{~m}, 5 \mathrm{H}), 3.47-3.45(\mathrm{~m}, 2 \mathrm{H}), 3.60-3.56(\mathrm{~m}, 2 \mathrm{H}), 2.47-$ $2.43(\mathrm{~m}, 2 \mathrm{H}), 2.46(\mathrm{~s}, 3 \mathrm{H}) .{ }^{19} \mathrm{~F} \mathrm{NMR}\left(\mathrm{CDCl}_{3}, 376 \mathrm{MHz}\right)$ $\delta:-223.30\left(\mathrm{tt},{ }^{2} J_{\mathrm{HF}}=47.7 \mathrm{~Hz},{ }^{3} J_{\mathrm{HF}}=29.5 \mathrm{~Hz}\right)$. HR-MS calcd. for $\mathrm{C}_{14} \mathrm{H}_{23} \mathrm{FN}_{3} \mathrm{O}_{3} \mathrm{~S}[\mathrm{M}+1]$ : 332.1439; found: 332.1434. EA calcd.: C 50.74, H 6.69, N 12.68; found: C $50.87, \mathrm{H} 6.75, \mathrm{~N} 12.86$.

\section{3-(Hexyloxy)-4-(1-methyl-1,2,5,6-tetrahydropyridin-3-yl)- 1,2,5-thiadiazole (10)}

To an oven-dried round-bottomed flask, $71 \mathrm{mg}$ $(0.7 \mathrm{mmol})$ of 1-hexanol was added to $3 \mathrm{~mL}$ of freshly distilled THF. To the reaction mixture was added $34 \mathrm{mg}$ (1.4 mmol) of $95 \% \mathrm{NaH}$, and the mixture was allowed to stir at RT for $30 \mathrm{~min}$. Compound $\mathbf{1}(0.35 \mathrm{mmol})$ was subsequently added and the reaction was refluxed overnight. The reaction was diluted with $30 \mathrm{~mL}$ of $\mathrm{H}_{2} \mathrm{O}$ and washed with 
$30 \mathrm{~mL}$ of $\mathrm{CH}_{2} \mathrm{Cl}_{2}(\times 2)$. The combined organic layers were then washed with $40 \mathrm{~mL}$ of brine, dried over $\mathrm{Na}_{2} \mathrm{SO}_{4}$, and concentrated. The product was purified by PTLC (30:70 EtOAc:Hex $(v / v))$ and 9 was obtained in a yield of $58 \mathrm{mg}$ (60\%). ${ }^{1} \mathrm{H}$ NMR $\left(\mathrm{CDCl}_{3}, 300 \mathrm{MHz}\right) \delta: 7.09-7.04(\mathrm{~m}, 1 \mathrm{H})$, 4.47-4.41 (m, 2H), 3.48-3.43 (m, 2H), 2.61-2.55 (m, 2H), 2.49-2.42 (m, 5H), 1.89-1.78 (m, 2H), 1.52-1.39 (m, 2H), $1.38-1.31(\mathrm{~m}, 4 \mathrm{H}), 0.94-0.87(\mathrm{~m}, 3 \mathrm{H})$. HR-MS calcd. for $\mathrm{C}_{14} \mathrm{H}_{24} \mathrm{~N}_{3} \mathrm{OS}[\mathrm{M}+1]$ : 282.1635; found: 282.1633. EA calcd.: C 59.75, H 8.24, N 14.93; found: C 59.68, H 8.14, N 14.67.

\section{In vitro binding assays}

All $K_{\mathrm{i}}$ determinations were conducted by the National Institute of Mental Health's Psychoactive Drug Screening Program (NIMH PDSP), contract No. NO1MH32004. The NIMH PDSP is directed by Bryan L. Roth, M.D., Ph.D., at the University of North Carolina at Chapel Hill and Project Officer Jamie Driscol at NIMH, Bethesda, Maryland, USA (http://pdsp.med.unc.edu/).

\section{Radiochemical synthesis}

Synthesis of $\left[{ }^{18} \mathrm{~F}\right]-3-(2-(2-(2-$

fluoroethoxy)ethoxy)ethylthio)-4-(1-methyl-1,2,5,6tetrahydropyridin-3-yl)-1,2,5-thiadiazole $\left(\left[{ }^{18} \mathrm{~F}\right] 4 \mathrm{c}\right)$

A Scanditronix MC 17 cyclotron was used for $\left[{ }^{18} \mathrm{~F}\right]$ fluoride production and the radiosynthesis was carried out via general automated methods using a $\mathrm{GE}_{\mathrm{FX}} \mathrm{FN}$ radiofluorination module as previously reported in detail by our laboratory for the synthesis of $\left[{ }^{18} \mathrm{~F}\right] \mathbf{4 a},{ }^{14}$ with only minor modifications.

Briefly, to a reaction vessel containing reactive $\left[{ }^{18} \mathrm{~F}\right]$ fluoride was added $3 \mathrm{mg}$ of $\mathbf{3 c}$ dissolved in $500 \mu \mathrm{L}$ of $\mathrm{CH}_{3} \mathrm{CN}$. The reaction mixture was heated to $90{ }^{\circ} \mathrm{C}$ for $10 \mathrm{~min}$, and the reaction was quenched with $500 \mu \mathrm{L}$ of $\mathrm{H}_{2} \mathrm{O}$. The reaction mixture was then purified via semipreparative HPLC (20:80 $\mathrm{CH}_{3} \mathrm{CN}: \mathrm{H}_{2} \mathrm{O}+0.1 \mathrm{~N}$ ammonium formate $+1 \%$ formic acid $(\mathrm{pH} 4)$, Semi-Prep LUNA C18(2) $(250 \mathrm{~mm} \times$ $10 \mathrm{~mm}, 10 \mu \mathrm{m}, \lambda=254 \mathrm{~nm})$ ) at $6 \mathrm{~mL} / \mathrm{min}$. The major radiochemical peak $\left(t_{\mathrm{R}}=13 \mathrm{~min}\right)$ was collected and formulated as previously described. ${ }^{14}$ The formulated product was analyzed by HPLC $\left(30: 70 \mathrm{CH}_{3} \mathrm{CN}: \mathrm{H}_{2} \mathrm{O}+0.1 \mathrm{~N}\right.$ ammonium formate, Prodigy C18 ODS Prep column $(250 \mathrm{~mm} \times$ $4.6 \mathrm{~mm}, 10 \mu \mathrm{m}, \lambda=254 \mathrm{~nm}$ )) at a flow of $3 \mathrm{~mL} / \mathrm{min}$. HPLC analysis of formulated $\left[{ }^{18} \mathrm{~F}\right] \mathbf{4 c}$ revealed high radiochemical (>99\%) purities. Coinjection of the radioactive product with an authentic standard of $\mathbf{4} \mathbf{c}$ under several different HPLC conditions (solvents, $\mathrm{pH}$, wavelength; see Table S2 in the Supplementary data) with different analytical columns further established the identity of the radiotracer. Specific activity was calculated at the end of synthesis from the formulated product and was determined by integration of the UV peak of an analytical HPLC chromatogram in comparison with standard solutions containing known concentrations of $\mathbf{4 c}$.

\section{Ex vivo biodistribution}

Ex vivo biodistribution studies in conscious male Sprague-Dawley rats were conducted as previously described by our group. ${ }^{32,33}$ All rats received $\sim 2.6 \mathrm{MBq}$ of $\left[{ }^{18} \mathrm{~F}\right] \mathbf{4 c}$ in $0.3 \mathrm{~mL}$ of buffered saline via the tail vein and were sacrificed by decapitation at either $5,15,30$, or 60 min after injection ( $n=1$ per time point). The brains were removed and regions of interest (striatum, thalamus, hypothalamus, hippocampus, frontal cortex, rest of cortex, cerebellum, rest of brain, as well as whole blood from the trunk, bone, and heart) were excised, blotted, weighed, and then counted for radioactivity (Fig. 3).

\section{Metabolism studies}

Following tail-vein injection of $\left[{ }^{18} \mathrm{~F}\right] \mathbf{4 c}$ as described above, whole blood was collected at various time points from the trunk in a heparinized tube and centrifuged, and the plasma was separated for metabolite analysis by HPLC via the method of Hilton et al., ${ }^{35}$ with minor modifications. Briefly, rat plasma from each time point was directly loaded onto a $5 \mathrm{~mL}$ HPLC injector loop and injected onto a capture column $(4.6 \mathrm{~mm} \times 20 \mathrm{~mm})$ that was packed in-house with OASIS HLB $30 \mu \mathrm{m}$ (Waters, New Jersey). The capture column was eluted with $1 \%$ aqueous $\mathrm{CH}_{3} \mathrm{CN}(2 \mathrm{~mL} / \mathrm{min})$ for 3 min and then back-flushed $\left(19: 81 \mathrm{CH}_{3} \mathrm{CN}: \mathrm{H}_{2} \mathrm{O}+0.1 \mathrm{~N}\right.$ ammonium formate, $2.0 \mathrm{~mL} / \mathrm{min}$ ) onto a Phenomenex $10 \mu \mathrm{m}$ Luna C18 column $(250 \mathrm{~mm} \times 4.6 \mathrm{~mm})$. The column effluents from both columns were monitored through a flow detector (Bioscan Flow-Count) operated in coincidence mode. Whole brain removed from a control rat and treated with $\sim 1 \mathrm{MBq}$ of $\left[{ }^{18} \mathrm{~F}\right] \mathbf{4 c}$ and whole brain removed from a rat sacrificed at $60 \mathrm{~min}$ after injection of $\left[{ }^{18} \mathrm{~F}\right] \mathbf{4} \mathbf{c}$ in the tail vein were individually homogenized with ice-cold $80 \%$ ethanol and centrifuged as previously described by our laboratory, ${ }^{36}$ prior to radio-HPLC analysis of the supernatant using the aforementioned method.

\section{Supplementary data}

Supplementary data for this article are available on the journal Web site (canjchem.nrc.ca).

\section{Acknowledgements}

The authors gratefully acknowledge the assistance of Armando Garcia, Alvina Ng, Jun Parkes, Winston Stableford, and Min Wong for radioisotope production or biological evaluations, and acknowledge Dr. Matthew Moran and Dr. Karin Stephenson for helpful discussions. We also acknowledge Dr. Bryan Roth at the University of North Carolina at Chapel Hill and the National Institute of Mental Health's Psychoactive Drug Screening Program, contract No. NO1MH32004, for conducting $K_{\mathrm{i}}$ determinations and for helpful discussions. Funding for this work was provided by the Centre for Addiction and Mental Health (CAMH) as well as the Ontario Ministry of Research and Innovation (Early Researcher Award to N.V.).

\section{References}

(1) Caulfield, M. P. Pharmacol. Ther. 1993, 58 (3), 319. doi:10. 1016/0163-7258(93)90027-B.

(2) Eglen, R. M. Prog. Med. Chem. 2005, 43, 105. doi:10.1016/ S0079-6468(05)43004-0.

(3) Abrams, P.; Andersson, K.-E.; Buccafusco, J. J.; Chapple, C.; Chet de Groat, W.; Fryer, A. D.; Kay, G.; Laties, A.; 
Nathanson, N. M.; Pasricha, P. J.; Wein, A. J. Br. J. Pharmacol. 2006, 148 (5), 565. doi:10.1038/sj.bjp.0706780.

(4) Langmead, C. J.; Watson, J.; Reavill, C. Pharmacol. Ther. 2008, 117 (2), 232. doi:10.1016/j.pharmthera.2007.09.009.

(5) Ametamey, S. M.; Honer, M.; Schubiger, P. A. Chem. Rev. 2008, 108 (5), 1501. doi:10.1021/cr0782426.

(6) Miller, P. W.; Long, N. J.; Vilar, R.; Gee, A. D. Angew. Chem. Int. Ed. 2008, 47 (47), 8998. doi:10.1002/anie. 200800222.

(7) Eckelman, W. C. Curr. Pharm. Des. 2006, 12 (30), 3901. doi:10.2174/138161206778559678.

(8) Sauerberg, P.; Olesen, P. H.; Nielsen, S.; Treppendahl, S.; Sheardown, M. J.; Honore, T.; Mitch, C. H.; Ward, J. S.; Pike, A. J.; Bymaster, F. P.; Sawyer, B. D.; Shannon, H. E. J. Med. Chem. 1992, 35 (12), 2274. doi:10.1021/ jm00090a019.

(9) Farde, L.; Suhara, T.; Halldin, C.; Nyback, H.; Nakashima, Y.; Swahn, C. G.; Karlsson, P.; Ginovart, N.; Bymaster, F. P.; Shannon, H. E.; Foged, C.; Suzdak, P. D.; Sauerberg, P. Dementia 1996, 7 (4), 187.

(10) Kiesewetter, D. O.; Carson, R. E.; Jagoda, E. M.; Herscovitch, P.; Eckelman, W. C. Life Sci. 1999, 64 (6-7), 511. doi:10.1016/S0024-3205(98)00595-5.

(11) Kiesewetter, D. O.; Lee, J. T.; Lang, L.; Park, S. G.; Paik, C. H.; Eckelman, W. C. J. Med. Chem. 1995, 38 (1), 5. doi:10. 1021/jm00001a002.

(12) Reid, A. E.; Ding, Y.-S.; Eckelman, W. C.; Logan, J.; Alexoff, D.; Shea, C.; Xu, Y.; Fowler, J. S. Nucl. Med. Biol. 2008, 35 (3), 287. doi:10.1016/j.nucmedbio.2008.01.001.

(13) Kiesewetter, D. O.; Vuong, B.-k.; Channing, M. A. Nucl. Med. Biol. 2003, 30 (1), 73. doi:10.1016/S0969-8051(02) 00354-2.

(14) van Oosten, E. M.; Wilson, A. A.; Stephenson, K. A.; Mamo, D. C.; Pollock, B. G.; Mulsant, B. H.; Yudin, A. K.; Houle, S.; Vasdev, N. Appl. Radiat. Isot. 2009, 67 (4), 611. doi:10.1016/j.apradiso.2008.12.015.

(15) Eckelman, W. C. Nucl. Med. Biol. 2003, 30 (8), 851. doi:10. 1016/S0969-8051(03)00123-9.

(16) Jagoda, E. M.; Kiesewetter, D. O.; Shimoji, K.; Ravasi, L.; Yamada, M.; Gomeza, J.; Wess, J.; Eckelman, W. C. Neuropharmacology 2003, 44 (5), 653. doi:10.1016/S00283908(03)00050-9.

(17) Carson, R. E.; Kiesewetter, D. O.; Jagoda, E.; Der, M. G.; Herscovitch, P.; Eckelman, W. C. J. Cereb. Blood Flow Metab. 1998, 18 (10), 1130. doi:10.1097/00004647-19981000000010.

(18) Ichise, M.; Cohen, R. M.; Carson, R. E. J. Cereb. Blood Flow Metab. 2007, 28 (2), 420. doi:10.1038/sj.jcbfm. 9600530.

(19) Cohen, R. M.; Carson, R. E.; Filbey, F.; Szczepanik, J.; Sunderland, T. Synapse 2006, 60 (1), 86. doi:10.1002/syn.20276.

(20) Cohen, R. M.; Podruchny, T. A.; Bokde, A. L. W.; Carson,
R. E.; Herscovitch, P.; Kiesewetter, D. O.; Eckelman, W. C.; Sunderland, T. Synapse 2003, 49 (3), 150. doi:10.1002/syn. 10225.

(21) Podruchny, T. A.; Connolly, C.; Bokde, A.; Herscovitch, P.; Eckelman, W. C.; Kiesewetter, D. O.; Sunderland, T.; Carson, R. E.; Cohen, R. M. Synapse 2003, 48 (1), 39. doi:10. 1002/syn.10165.

(22) Benson, B. E.; Carson, R. E.; Kiesewetter, D. O.; Herscovitch, P.; Eckelman, W. C.; Post, R. M.; Ketter, T. A. Neuropsychopharmacology 2004, 29 (7), 1239. doi:10.1038/sj. npp.1300404.

(23) Cannon, D. M.; Carson, R. E.; Nugent, A. C.; Eckelman, W. C.; Kiesewetter, D. O.; Williams, J.; Rollis, D.; Drevets, M.; Gandhi, S.; Solorio, G.; Drevets, W. C. Arch. Gen. Psychiatry 2006, 63 (7), 741. doi:10.1001/archpsyc.63.7.741.

(24) Ferrari-DiLeo, G.; Mash, D. C.; Flynn, D. D. Mol. Chem. Neuropathol. 1995, 24 (1), 69. doi:10.1007/BF03160113.

(25) Kiesewetter, D. O.; Jagoda, E. M.; Shimoji, K.; Ma, Y.; Eckelman, W. C. Nucl. Med. Biol. 2007, 34 (2), 141. doi:10. 1016/j.nucmedbio.2006.11.002.

(26) Kane, B. E.; Grant, M. K.; El-Fakahany, E. E.; Ferguson, D. M. Bioorg. Med. Chem. 2008, 16 (3), 1376. doi:10.1016/j. bmc.2007.10.058.

(27) Rajeswaran, W. G.; Cao, Y.; Huang, X.-P.; Wroblewski, M. E.; Colclough, T.; Lee, S.; Liu, H.; Nagy, P. I.; Ellis, J.; Levine, B. A.; Nocka, K. H.; Messer, W. S., Jr. J. Med. Chem. 2001, 44 (26), 4563. doi:10.1021/jm0102405.

(28) Tejada, F. R.; Nagy, P. I.; Xu, M.; Wu, C.; Katz, T.; Dorsey, J.; Rieman, M.; Lawlor, E.; Warrier, M.; Messer, W. S., Jr. J. Med. Chem. 2006, 49 (25), 7518. doi:10.1021/jm0606995.

(29) Zhang, W.; Oya, S.; Kung, M.-P.; Hou, C.; Maier, D. L.; Kung, H. F. Nucl. Med. Biol. 2005, 32 (8), 799. doi:10. 1016/j.nucmedbio.2005.06.001.

(30) Hudkins, R. L.; DeHaven-Hudkins, D. L. Life Sci. 1991, 49 (17), 1229. doi:10.1016/0024-3205(91)90135-X.

(31) Wilson, A. A.; Jin, L.; Garcia, A.; DaSilva, J. N.; Houle, S. Appl. Radiat. Isot. 2001, 54 (2), 203. doi:10.1016/S09698043(00)00269-4.

(32) Vasdev, N.; Natesan, S.; Galineau, L.; Garcia, A.; Stableford, W. T.; McCormick, P.; Seeman, P.; Houle, S.; Wilson, A. A. Synapse 2006, 60 (4), 314. doi:10.1002/syn.20304.

(33) Wilson, A. A.; DaSilva, J. N.; Houle, S. Nucl. Med. Biol. 1996, 23 (2), 141. doi:10.1016/0969-8051(95)02044-6.

(34) Cox, D. P.; Terpinski, J.; Lawrynowicz, W. J. Org. Chem. 1984, 49 (17), 3216. doi:10.1021/jo00191a035.

(35) Hilton, J.; Yokoi, F.; Dannals, R. F.; Ravert, H. T.; Szabo, Z.; Wong, D. F. Nucl. Med. Biol. 2000, 27 (6), 627. doi:10. 1016/S0969-8051(00)00125-6.

(36) Wilson, A. A.; Garcia, A.; Parkes, J.; McCormick, P.; Stephenson, K. A.; Houle, S.; Vasdev, N. Nucl. Med. Biol. 2008, 35 (3), 305. doi:10.1016/j.nucmedbio.2007.12.009. 